\title{
1. Cross-border dimension of collective proceedings in the Brussels Ibis regime: jurisdiction, lis pendens and related actions

\author{
T.M.C. Arons
}

\section{INTRODUCTION}

Efficiency is best served in mass damage cases by collective redress. Furthermore, collective redress enhances access to justice. Collective redress means that individual claims that may not be settled out of court, or brought to court in two-party adversarial proceedings, because of litigation costs and risks are dealt with at an aggregate or collective level. This dealing can take the form of litigation in collective action proceedings or a collective settlement.

Collective redress is wide-ranging, including assignment of individual claims to a claim vehicle (a special purpose vehicle, SPV), or a truly collective claim brought in its own right by a representative organisation (in most cases associations or foundations) that claims either for damages or a declaratory ruling on breach of contract or tortiousness of the behaviour by the defendant towards the represented group of (legal) persons.

Both in collective action proceedings and in a collective settlement, courts are involved in order either to rule on the (collective) claim or to give an out of court settlement third party effect by declaring it binding on a defined group of persons not individually involved in the settlement. By collective claim, I refer to claims made by a representative organisation in the interest of a defined group of injured parties, which deal with the matter at a group or collective level. The court ruling is abstract by nature because it is concerned with the legal relationship between the defendant and the group, not the individual members thereof. Collective claims in this sense do not refer to individual claims that are collectivised by bundling them in one hand through assignment thereof to one single entity.

In case of cross-border mass damage, collective redress is unthinkable without an adequate system of rules regarding jurisdiction in collective proceedings. ${ }^{1}$ Collective action proceedings and collective settlement proceedings before courts in member states of the European Union are an increasingly frequent phenomenon. In the financial sector in particular, collective redress is frequently used as an instrument to settle claims. Investors (and their litigation funders) frequently sue financial institutions, ${ }^{2}$ or companies issuing shares and bonds to the public, in cases of alleged corporate misinformation or fraud, in so-called federal securities class actions.

1 See: A-G Bobek in his Conclusion of 14 November 2017 in Case C-498/16, ECLI:EU:C:2017:863 (Schrems/Facebook Ireland Ltd) paras 119-123.

2 This term encompasses all companies regulated and/or supervised by financial sector supervisors. Cf. art. 1:1 'financiële onderneming' Wft. 


\section{Research handbook on the Brussels Ibis Regulation}

Unlike in the US, there is no collective action or collective settlement procedure enacted at the EU level. ${ }^{3}$ Currently, the EU issues only recommendations, and the EU legislation to be expected in the near future sets only minimum standards. Therefore, the different national law systems of the member states provide the collective redress mechanisms available to injured parties and representative organisations. Because of this lack of harmonised rules of collective action or settlement proceedings, the injured parties and representative organisations have an incentive to bring their (collective) before the court with the most suitable collective redress mechanisms. Furthermore, mass damage cases may affect parties in more than one member state. In these cases, private international law issues such as jurisdiction, lis pendens, staying because of related actions and recognition of judgments have to be dealt with by the courts addressed. Unlike the collective redress rules themselves, the private international law rules are maximally harmonised at the EU level almost two decades. ${ }^{4}$ The Brussels Ibis regulation provides a harmonised set of rules to be applied by every court in a member state addressed by claims involving civil or commercial matters. ${ }^{5}$

The court of the member state in which the defendant is domiciled (forum rei) has jurisdiction - excepted are other exclusively competent courts - for all claims filed by the claimant against this defendant, irrespective of the basis of this claim and its nature. ${ }^{6}$ Collective redress claims (whether bundled individual claims or truly collective claims) can be heard by the forum rei on the basis of article 4 Brussels Ibis regulation or the national equivalent in civil procedural law.

National courts may derive competence to hear a claim from the special jurisdiction rules laid down in section 2 of chapter II of the Brussels Ibis regulation. In particular, the question arises if, and under what conditions, a collective claim may be sued in the court for the place where the harmful event occurred or may occur. In particular, the question arises whether the court where the initial losses are sustained (Erfolgsort) has jurisdiction to hear the collective claim. In principle, the collective nature of the claim does not prevent the application of these special jurisdiction rules of the Brussels Ibis regulation. ${ }^{7}$ The location of the harmful event must be assessed for each claim for damages independently of any subsequent assignment or consolidation. Nonetheless, collectivising or bundling of claims by assignment to a special purpose vehicle does not provide the assignee, that is the SPV, a new forum to claim. ${ }^{8}$ On

Rule 23 Federal Rules of Civil Procedure.

On 1 March 2002 the Brussels I regulation entered into force (art. 76 BrI reg).

Regulation (EU) No 1215/2012 of the European Parliament and of the Council of 12 December 2012 on jurisdiction and the recognition and enforcement of judgments in civil and commercial matters [2012] OJ L351/1.

6 See ECJ 5 October 1999 Case C-420/97, ECLI:EU:C:1999:483 (Leathertex Divisione Sintetici SpA/Bodetex BVBA) para 41.

7 ECJ 21 May 2015 Case C-352/13, ECLI:EU:C:2015:335 (Cartel Damage Claims (CDC) Hydrogen Peroxide SA/Akzo Nobel NV) paras 35-36: 'Given that the circumstances of the present case are characterised by the consolidation of a number of potential claims for damages brought by the applicant in the main proceedings which had been assigned to the applicant by several undertakings allegedly victims of the Hydrogen Peroxide cartel, it should be pointed out from the outset that the transfer of claims by the initial creditor cannot, by itself, have an impact on the determination of the court having jurisdiction under Article 5(3) of Regulation No 44/2001 (judgment in ÖFAB, C-147/12, EU:C:2013: 490, paragraph 58).'

8 ECJ 21 May 2015 Case C-352/13, ECLI:EU:C:2015:335 (CDC/Degussa), para 35 referring to ECJ 18 July 2013 Case C-147/12, EU:C:2013:490 (ÖFAB/Koot) para 58. 
the basis of article 16 Brussels Ibis regulation a consumer is entitled to bring legal proceedings before the courts of his domicile regarding claims vested in rights under a contract this consumer concluded with the defendant. However, the scope of article 16 is not extended to claims that have been assigned to this consumer even though these claims concern rigts under a similar contract concluded with the same defendant. Proceedings concerning assigned claims cannot be brought within the jurisdiction of that court on the basis of article 16 Brussels Ibis regulation. ${ }^{9}$ A similar rule applies to claims assigned to a special purpose vehicle: for each and every claim, the competent court has to be established individually. Special jurisdiction for one claim does not confer jurisdiction in regard of the other (assigned) claims. In the absence of any specific rules regarding collective proceedings in the Brussels Ibis regulation, the national courts have to derive their jurisdiction to hear the collective claim - irrespective of whether it is a bundling of individual claims by one claimant or a claim in its own right by a representative organisation - on the jurisdiction rules applicable to the (underlying) ${ }^{10}$ claims of the original individual aggrieved parties.

In this chapter the focus is on the consequences of the cross-border dimension for collective redress claims filed at courts in member states. For the sake of clarity, rules and conditions of the national collective redress mechanisms will have to be taken into account in order to understand the private international law problems arising in those proceedings. Questions of lis pendens and related actions arise in the case that courts in different member states are addressed involving the same or a similar cause of action and between one or two of the same parties. In particular, this chapter focuses on related proceedings in courts of another member state. The nature of the court judgment's binding effect on the collective claim or collective settlement is important when the question of recognition arises. Which parties' rights are affected by recognising the collective action or settlement judgment?

This chapter has the following structure. Section 2 discusses the legislative history of the Brussels Ibis regulation in relation to collective action or settlement proceedings. In section 3 the collective redress mechanisms in three member states (France, Germany and the Netherlands) are analysed. Section 4 deals with jurisdiction rules in collective proceedings under the Brussels Ibis regulation regime. International aspects of claims may determine the admissibility under national collective procedural law. This is dealt with in section 5 . In section 6 the rules on lis pendens, related actions and recognition of Brussels Ibis regulation are explained in terms of their consequence in collective proceedings. Section 7 provides for some concluding remarks.

\footnotetext{
9 ECJ 25 January 2018 Case C-498/16, ECLI:EU:C:2018:37 (Schrems/Facebook Ireland Ltd) paras $47-48$.

10 On the basis of art. 3:305a of the Dutch Civil Code (BW) an association or foundation files a claim in his own right (i.e. not mandated) in the interest of the group of persons allegedly injured by the defendant. With this independent claim (in most cases a declaratory that the defendent behaved tortiously towards the aforementioned group) the interests of the members of this group are served. The respective claims of the members of this group individually are underlying claims, i.e. the claims in whose interest the declaratory is sought by the association or foundation.
} 


\section{LEGISLATIVE HISTORY OF THE BRUSSELS IBIS REGULATION}

One of the key elements of the recast Brussels Ibis regulation is the abolition of the exequatur. The intermediate procedure for the recognition and enforcement of judgments was abolished except for defamation cases and judgments given in collective compensatory proceedings. In the explanatory memorandum to the legislative proposal it was explained that the stakeholders - consulted by the Commission - expressed specific concerns with respect to the abolition of the exequatur in collective redress proceedings. ${ }^{11}$ Collective redress mechanisms were defined by the Commission in the explanatory memorandum as "proceedings brought by a group of claimants, a representative entity or a body acting in the public interest and which concern the compensation of harm caused by unlawful business practices to a multitude of claimants'. ${ }^{12}$

The Commission recognised the wide ranging differences in collective redress mechanisms in the member states. ${ }^{13}$ The different characteristics of the relative side of the binding effect of the judgments rendered (opt-in versus opt-out), the nature of the claimant initiating the collective proceedings (individual claimant or representative organisation), the legal standing requirements of the claimants (private or officially recognised organisation; corporate governance requirements), the nature of the judgment (abstract judgment by the court itself or judgment on individual claims on the basis of judgment by higher court ruling on the factual and legal questions common to various individual claims); single or multilevel proceeding (truly collective judgment versus reference procedure); generally applicable or sector-specific collective proceedings, the funding of collective redress actions, the distribution of proceeds. These differences still exist and may have become even more prominent.

Because of these differences and the fact that there was a pending consultation on a European approach to collective redress to identify which forms of collective redress could fit into the EU legal system and into the legal orders of the member states, no automatic recognition of judgments in collective proceedings was deemed suitable. The Commission wanted to use the outcomes of this consultation to determine how efficient the rules on European civil and procedural law are for collective actions and judgments to be enforceable through the EU. ${ }^{14}$ Therefore, the Commission deemed it wise to preserve the status quo. ${ }^{15}$

For this purpose, the original proposal for a Brussels Ibis regulation introduced in article $37(3)(b)$ the provision that exequatur or recognition requirements applies to

11 Proposal for a Regulation of the European Parliament and of the Council on jurisdiction and the recognition and enforcement of judgments in civil and commercial matters, (Recast), COM(2010) 748 final 2010/0383 (COD), pp.5-6.

12 Proposal for a Regulation of the European Parliament and of the Council on jurisdiction and the recognition and enforcement of judgments in civil and commercial matters (Recast), COM(2010) 748 final 2010/0383 (COD), p.7.

13 Proposal for a Regulation of the European Parliament and of the Council on jurisdiction and the recognition and enforcement of judgments in civil and commercial matters (Recast), COM(2010) 748 final 2010/0383 (COD), p.7.

14 Proposal for a Regulation of the European Parliament and of the Council on jurisdiction and the recognition and enforcement of judgments in civil and commercial matters (Recast), COM(2010) 748 final 2010/0383 (COD), p.7.

15 See recital 32 of the Preamble to the Proposal. 
judgments given in another Member State in proceedings which concern the compensation of harm caused by unlawful business practices to a multitude of injured parties and which are brought by $i$. a state body, ii. a non-profit making organisation whose main purpose and activity is to represent and defend the interests of groups of natural or legal persons, other than by, on a commercial basis, providing them with legal advice or representing them in court, or iii. a group of more than twelve claimants.

The European Economic and Social Committee did not regard these reasons substantial enough to exclude collective proceedings when abolishing the exequatur. So the ESC advised the Commission to modify article 37. The ESC reiterated its support for a supranational regulation of collective proceedings. It advised the Commission to consider amending Article 6 of Regulation 44/2001 (Brussels I regulation) in order to allow actions brought by different claimants to be dealt with collectively, providing that the grounds for their cases are so closely linked that it is appropriate to process and pronounce judgment on them at the same time, so as to avoid decisions which could be incompatible if cases were dealt with separately. ${ }^{16}$

Despite the continued differences in collective redress mechanisms in the EU member states, the final version of the Brussels Ibis regulation adopted by the European Parliament and the Council does not provide for an exception to recognition in collective proceedings. More importantly, the Brussels Ibis regulation does not provide for any special mechanism for courts to deal with private international law issues arising in collective proceedings. The aforementioned article 6 Brussels I regulation has not been amended but has been renumbered in article 8 Brussels Ibis regulation. It still only provides for a mechanism to consolidate claims against multiple defendants before a single court. ${ }^{17}$ Article 8 does not provide for consolidation of claims in the same or similar matter by multiple claimants against the same defendant(s).

Therefore, the jurisdiction, lis pendens and recognition rules applicable in two-party adversarial proceedings apply in collective proceedings as well. The only rule newly introduced in the Brussels Ibis regulation is the rule on related actions (article 30 Brussels Ibis regulation). Thereby, courts may stay proceedings if a related action is pending before the courts of another member state. ${ }^{18}$ Where the action in the court first seised is pending at first instance, any other court may also, on the application of one of the parties, decline jurisdiction if the court first seised has jurisdiction over the actions in question and its law permits the consolidation thereof. ${ }^{19}$ Actions are deemed to be related where they are so closely connected that it is expedient to hear and determine them together to avoid the risk of irreconcilable judgments resulting

16 Opinion of the European Economic and Social Committee on the 'Proposal for a Regulation of the European Parliament and of the Council on jurisdiction and the recognition and enforcement of judgments in civil and commercial matters' COM(2010) 748 final - 2010/0383 (COD), 2011/C 218/14 [2010] OJ C218/78, para 4.3.1.

17 On the basis of art. 8 Brussels Ibis reg. A person domiciled in a Member State may also be sued where he is one of a number of defendants, in the courts for the place where any one of them is domiciled, provided the claims are so closely connected that it is expedient to hear and determine them together to avoid the risk of irreconcilable judgments resulting from separate proceedings.

18 Art. 30(1) BrIbis reg.

19 Art. 30(2) BrIbis reg. 


\section{Research handbook on the Brussels Ibis Regulation}

from separate proceedings. ${ }^{20}$ Unlike lis pendens, it is not required that the actions are between the same parties. ${ }^{21}$

However, as will be concluded in Chapter 5, in reality courts in the member states are reluctant to stay proceedings in (collective) action proceedings even though the substantive matter in the actions before the courts in the different member states are similar and related to the same alleged tortious behaviour of the defendant.

\section{COLLECTIVE ACTION AND SETTLEMENT PROCEEDINGS}

\subsection{European Union Legislation on Collective Proceedings}

In 2013 the Commission issued recommendations on common principles for injunctive and compensatory collective redress mechanisms in the member states concerning violations of rights granted under Union law. ${ }^{22}$ On 25 January 2018 the Commission published a report on its implementation. ${ }^{23}$ In April 2018, this evaluation resulted in a proposal for a directive on representative actions for the protection of the collective interests of consumers. ${ }^{24}$ The scope of the procedure proposed in this directive is not general. ${ }^{25}$ The proposal seeks to introduce representative actions available to qualified entities designated by the member states. ${ }^{26}$ Out of court settlements need court approval to have third party effect, that is, to bind the parties whose interests are represented. ${ }^{27}$ The representative entity has to be able to get the following court judgment: collective redress orders and declaratory decisions establishing the trader's liability towards the consumers harmed by the infringements of EU law. ${ }^{28}$

Despite these harmonisation efforts by the EU legislator, not even the proposed directive will change the fact that the relevant differences between the collective proceedings in the member states - as observed in 2010 at the original proposal for a Brussels Ibis regulation

\footnotetext{
20 Art. 30(3) BrIbis reg.

21 Proposal for a Regulation of the European Parliament and of the Council on jurisdiction and the recognition and enforcement of judgments in civil and commercial matters (Recast), COM(2010) 748 final 2010/0383 (COD), p.9.

22 Commission Recommendation of 11 June 2013 on common principles for injunctive and compensatory collective redress mechanisms in the Member States concerning violations of rights granted under Union Law [2013] OJ L201/60.

23 Report from the commission to the European Parliament, the Council and the European Economic and Social Committee on the implementation of the Commission Recommendation of 11 June 2013 on common principles for injunctive and compensatory collective redress mechanisms in the Member States concerning violations of rights granted under Union law (2013/396/EU), COM(2018) 40 final.

24 Proposal for a Directive of the European Parliament and of the Council on representative actions for the protection of the collective interests of consumers, and repealing Directive 2009/22/EC, COM(2018)184 final, 2018/089 (COD).

25 The procedure should apply as sector-specific EU instruments to protect collective interests of consumers in different economic sectors regulated by EU law, such as financial services, energy, telecommunications, health and the environment.

26 Art. 4-5 proposal. The following minimum qualification criteria apply: the organisation must be properly established, not for profit and have a legitimate interest in ensuring compliance with the relevant EU law.

27 Art. 8 proposal.

28 Art. 6 proposal.
} 
- remain significant. The different characteristics of the collective proceedings will affect the private international law issues of lis pendens, related actions and recognition. Courts in member states will have to rule on whether the claim brought before them should be stayed because it is allegedly related to collective proceedings before the courts of another member state. Furthermore, the matter may have been dealt with in expired collective proceedings. The court has to rule on the recognition of the collective judgment or collective settlement. The binding nature of that judgment is determined by the lex fori. For these reasons national laws concerning collective proceedings are important for the application of the Brussels Ibis regulation.

In the following subsections, the laws of France, Germany and the Netherlands are analysed. These jurisdictions cover a wide range of varieties of models for collective action or settlement proceedings.

\subsection{French Collective Action Proceedings}

After many earlier stranded bills, with the Hamon Act the French legislator finally adopted collective action proceedings in French civil law. This collective action (action de groupe) was enacted in the Consumer Code (Code de la consommation, C. consomm.). ${ }^{29}$

The new chapter III (action de groupe) of Title II of book IV of the Consumer Code (art. L423-1 - art. L423-26 C. consomm.) entered into force on 19 March 2014. Because of the constitutionally protected individual access to court, ${ }^{30}$ the French collective action is - based on the opt-in model. Of the group in whose interest the collective action was brought before the court, only those members that explicitly made themselves known are bound. However, the French legislator has explicitly enacted that the individual group members do not have to be known to the litigating parties and the court when the latter rules on the definition of the group and the defendant's liability towards the group. ${ }^{31}$ The French collective action has few formal requirements and regulations. ${ }^{32}$ Much is left to judicial autonomy.

On the basis of art. L.423-1 C. consomm., associations officially recognised by the French government (associations agréés) may act in the common interest of consumers by filing claims at the civil court in order to obtain compensation for the individual damages sustained by consumers. The consumers need to have sustained damages in an identical or similar

29 Loi $n^{\circ}$ 2014-344 du 17 mars 2014 relative à la consommation. After endorsement by the Constitutional Council (Conseil consitutionnel) in its decision of 12 March 2014, ECLI:FR:CC:2014: 2014.690.DC, JORF 2014/65, n², 18 mars 2014, p.5450, the law was proclaimed by presidential order, JORF 2014/65, 18 mars 2014, $\mathrm{n}^{\circ} 2$, p.5400.

30 Decision by the Conseil Constitutionel of 25 July 1989, ECLI:FR:CC:1989:89.257.DC, JORF 1989, 28 juillet 1989, p.9503; referred to in the following parliamentary document: Sénat, $N^{\circ} 809,24$ jullet 2013, Rapport fait au nom de la commission des affaires économiques (1) sur le projet de loi, adopté par l'Assemblée nationale. relatif à la consommation, M. Bourquin et A. Fauconnier, pp.34-5.

31 See: Assemblée nationale, $\mathrm{n}^{\circ} 1156,13$ juin 2013, Rapport fait au nom de la commission des affaires économiques sur le projet de loi relative à la consommation, R Hammadi et A. Le Loch, p.60.

32 For an overview I refer to: M. Bacache, 'Action de groupe et responsabilité civile', RTD Civ. 2014, 24 juillet 2014, p.450; E. Claudel, 'Action de groupe et autres dispositions concurrence de la loi consommation: un dispositif singulier', RTD Com. 2014, 30 juillet 2014, p.339; N. Molfessis, 'L'exorbitance de l'action de groupe à la française', D. 2014, 1 mai 2014, p.947. 


\section{Research handbook on the Brussels Ibis Regulation}

situation. This situation has a common ground (cause commune) in a violation of the (pre) $)^{33}$ contractual legal obligations by the person(s) trading in a professional or business capacity (professionel) $^{34}$ at the sale of a good or service, or losses incurred as a result of violations of (EU) competition law. ${ }^{35}$ In the debate in the French Parliament it was made clear by the Minister that 'sale of a good or service' must be interpreted such that also pure economic losses incurred by consumer-investors as a result of financial services provided to them or securities and financial products offered to them fall within the scope of application. Examples given were violation of information, advisory or warning duties by banks or professional service providers. ${ }^{36}$

The structure of the French collective proceedings is as follows. It consists of three stages. At stage 1 the court rules on the admissibility of the association and its claim as well as the liability of the defendant for its alleged behaviour towards the consumers specifically mentioned as examples by the association in its writ of summons.$^{37}$ In its ruling, the court also need to address: (1) a class description and selection criteria; (2) the reimbursable loss items for each (category of) consumer(s); (3) the (individual or categorical) compensation; and (4) the compensation evaluation criteria. ${ }^{38}$

If this stage 1 ruling is no longer appealable, the court will order the manner in which its ruling shall be made public. ${ }^{39}$ The court determines the opt-in period (2-6 months) in which the individual member of the group have to register at the court, the defendant or at the association or judicial authority as appointed by the court in its ruling. ${ }^{40}$

When the identity and number of the consumers involved in the harmful event are known at the start and the amount of damages is identical, the court may immediately order the defendant to directly pay the compensation to these consumers. ${ }^{41}$

At stage 2, the court will determine which kind of losses will be compensated either for each individual consumer or for defined categories of consumers. In the same judgment it will also rule on the method used to calculate the damages to be awarded individually or categorically.

33 Cf. Ministerial reaction to Amendement CE345 of T. Benoit. This amendment restricted the scope to contractual obligations. It was rejected in the French Parliament. Assemblée nationale, $N^{\circ} 1574,21$ novembre 2013, Rapport fait au nom de la commission des affaires économiques sur le projet de loi, modifié par le Sénat, relatif à la consummation ( $\left.{ }^{\circ} 1357\right)$, R. Hammadi et A. Le Loch, p.40.

34 At the request of the French Senate the possibility was introduced that consumer associations can claim against multiple defendants in one procedure for identical or similar matters. See Sénat, $\mathrm{N}^{\circ} 282$, 15 janvier 2014, Rapport fait au nom de la commission des affaires économiques (I) dur le projet de loi, adopté pas l'Assemblée nationale, relatif à la consommation, M. Bourquin et A. Fauconnier.

35 Art. L623-1 C. consomm. Please note that in art. 85 of the Act of 18 November 2016 (Loi de modernisation de la justice du $21^{e}$ siècle) the material scope has to be broadened to include actions for the protection against harms to: (a) discrimination; (b) environment; (c) health; (d) personal data. Furthermore, this Act also introduced an identical collective procedure before the administrative court (Chapter X t/m XII of Title VII of Book VII Code de justice administrative).

${ }_{36}$ Ministerial reaction to Amendement CE31 of D. Abad, Assemblée nationale, № 1574, 21 novembre 2013, Rapport fait au nom de la commission des affaires économiques sur le projet de loi, modifié par le Sénat, relatif à la consummation ( $\left.\mathrm{n}^{\circ} 1357\right)$, R Hammadi et A. Le Loch, p.42.

37 Art. L623-4 C. consomm.

38 Art. L623-1 C. consomm.

39 Art. L623-8 C. consomm.

40 Art. L623-5 C. consomm. jo. art. L423-9 C. consomm.

${ }^{41}$ Art. L623-14 C. consomm. 'Procédure d'action de groupe simplifiëe'. 
Stage 3 is centred on execution. In principle, the French legislator assumes that the defendant will, in accordance with the stage 1 ruling, pay the compensation due to the individual consumers. ${ }^{42}$ Should there be any conflict regarding the execution of its ruling, the court will issue one ruling on all compensation claims that were not finally dealt with. ${ }^{43}$ In these proceedings these individuals will be represented on the basis of art. L623-19 C. consomm. by the involved consumer association. ${ }^{44}$

In the case that the parties do not settle, the court will give a ruling in stage 2 how the individual members of the group have to be compensated. It can provide for a calculation mechanism of damages to be awarded on an individual basis or per category. Please note that this ruling is quite similar to the ruling the Dutch courts will give when the new collective action proceedings enter into force. Unlike Dutch law, French law specifically provides how courts have to solve problems arising in the execution of the judgment (stage 3).

The litigating parties may, at any stage before and during the court proceedings, conclude an out of court settlement. This settlement needs court approval in order to provide binding effect on the group. The court will assess whether the settlement is in the interest of the consumers affected. The settlement has only binding effect on those consumers that opt in (adhésion) during the term set by the court in its approval ruling. ${ }^{45}$ So, unlike the Dutch WCAM proceedings, the French collective proceedings do not provide for an opt-out settlement model where all member of the group are bound by the settlement unless they explicitly opt out.

\subsection{German Collective Action Proceedings}

\subsubsection{Capital Markets Model Case (KapMuG) proceedings}

Legislation introducing collective proceedings were recently adopted in German law. In 2005 the German Capital Markets Model Case Proceedings Act (Kapitalanleger-Musterverfahren sgesetz, KapMuG) entered into force. ${ }^{46}$ One of the major driving forces behind the KapMuG was the Deutsche Telekom case.

In 2000, Deutsche Telekom, a German (mobile) phone operator, issued shares on the Frankfurt Stock Exchange as part of the privatisation of the company. Prior to the issue, Deutsche Telekom published and distributed a prospectus. The share price was determined at EUR 66.50 per share. However, soon after the issue, the share price of Deutsche Telekom fell quite considerably. A high number of investors who suffered losses on this transaction started individual court proceedings against Deutsche Telekom. They claimed damages for the losses they incurred as a result of the publication of a prospectus allegedly containing misleading statements.

\footnotetext{
42 Art. L623-18 C. consomm.

43 Art. L623-19 C. consomm.

44 According to the normal rules, the legal costs of the association will be borne by the defendant. Art. L623-20 C. consomm. jo. art. L111-8 Code de procédures civiles d'exécution, CPCE.

45 Art. L423-23 C. consomm.

46 BGBl. I 2005, S. 2437. This Act has been replaced by the entry into force of KapMuG-ReformG (Gesetz zur Reform des Kapitalanleger-Musterverfahrensgesetzes und zur Änderung anderer Vorschriften), BGB1. I 2012, S. 2182.
} 
In order to alleviate the courts from the burden to deal with the vast number of identical individual claims against the same defendants, the German legislator introduced the KapMuG. ${ }^{47}$ German private law did not provide explicit rules on model case proceedings. Without a statutory regulation and due to traditional res judicata rules, a court judgment in a model case selected by the group of claimants and the defendant has no binding effect upon the other members of the group which are not a formal party to the court proceedings. ${ }^{48}$

The KapMuG also aims to facilitate court access and compensation for investors that suffered a relatively small loss relative to the costs and risks of litigation. ${ }^{49} \mathrm{In} \mathrm{KapMuG}$ proceedings (Musterverfahren), Higher Regional Courts (Oberlandesgericht, OLG) rule with binding effect on factual and legal issues that these claims have in common. The use of this method of collective redress in mass claims is limited to damage claims for losses suffered as a result of false or misleading information disseminated on public capital markets. ${ }^{50}$

A district court (Landgericht, LG) may at the request of (one of the) litigating parties initiate a collective procedure. ${ }^{51}$ A precondition is that the individual dispute needs to be solved by answering questions of law and/or fact that it has in common with other claims. If the LG rules that there is sufficient ground to establish that its decision in the pending case depends on establishing an element of liability or an answer to a legal question that is common to more court proceedings, ${ }^{52}$ it stays proceedings and makes a public announcement in the KapMuG register of the electronic version of the German State Gazette (Bundesanzeiger).$^{53}$ In the case that, within six months of registration, at least nine requests to initiate model case proceedings have been made in cases concerning similar claims, the OLG selects one of the claimants as the model case claimant. ${ }^{54}$ In the model case proceedings, the OLG rules with binding effect on the common factual and legal issues.

During the model case procedure before the OLG, other cases concerning claims in which one of these common factual and/or legal issues also arise are stayed ex officio until the OLG has given its model case ruling (Musterentscheid). ${ }^{55}$ This ruling is binding in the sense that

47 German scholars were not convinced that this Act would solve the problem of overburdening the courts as long as all claimants would, as third parties to the model case proceedings, have the right to participate in those proceedings. According to them, the only practical solution would be to introduce an opt-out procedure which happened in the KapMuG Reform Act 2012. See: J. Jahn, 'Der Telekom-Prozess: Stresstest für das Kapitalanleger-Musterverfahrensgesetz' (2005) ZIP 29, p.1317. In practice, these problems seem to be overcome quite efficiently by the use of electronic means. See the KapMuG-evaluation: A. Halfmeier, P. Rott and E. Fees, Kollektiver Rechtsschutz im Kapitalmarktrecht: Evaluation des Kap italanleger-Musterverfahrensgesetzes, Banking \& Finance aktuell, Band 40 (Frankfurt School) 2010, p.30; pp.54-5. In particular, the uniform provision of evidence and the enhancement of legal certainty by the factual binding effect of early decisions by the German Court of Justice are regarded advantageous.

48 A. Stadler, 'Group actions as a remedy to enforce consumer interests' in: F. Cafaggi and H.-W. Micklitz (eds), New Frontiers of Consumer Protection: The Interplay Between Private and Public Enforcement (Intersentia) 2009, p.313.

49 Bill and Explanatory Notes to the Capital Markets Model Case Act (Entwurf eines Gesetzes zur Einführung von Kapitalanleger-Musterverfahren) BT-Drs. 15/5091, p.13.

$50 \$ 1$ KapMuG.

$51 \S 2(1) \mathrm{KapMuG}$. The LG may not ex officio start the KapMuG proceedings.

$52 \S 3(1) \mathrm{KapMuG}$.

$53 \S 3(2) \mathrm{KapMuG}$.

$54 \S 6(1) \mathrm{KapMuG}$ jo. $\S 9$ (2) KapMuG.

$55 \S 8 \mathrm{KapMuG}$. 
the LGs have to apply this ruling in their decisions on the pending claims. ${ }^{56}$ The individual circumstances of each claimant will be dealt with by the LGs when they resume the pending proceedings after the model case ruling. Issues of fault on the part of the claimant, and of causation, that are not common to all claimants remain to be decided by the lower courts when they rule upon the claim for damages.

An example is again the Deutsche Telekom case. On 21 October 2014 the German Supreme Court (Bundesgerichtshof, BGH) upheld the OLG's KapMuG decision that the prospectus was indeed misleading. ${ }^{57}$ The $\mathrm{BGH}$ also ruled that individual circumstances like causation cannot be decided in model case proceedings. The questions need to be addressed by the LG in the individual cases.

One of the basic features of the KapMuG is the opt-in character. Only similar claims against the common defendant(s) brought before the LG are subject to the binding effect of the Musterentscheid. Furthermore, only in regard of claims brought before the courts, or registered at the $\mathrm{OLG},{ }^{58}$ is the limitation period of the claim interrupted. ${ }^{59}$ The KapMuG's material scope is limited to claims for damages related to corporate misinformation in a prospectus, violation of disclosure duties by listed companies, ${ }^{60}$ and contractual claims regarding the offer and sale of securities. ${ }^{61}$

On 1 November 2012 the KapMuG Reform Act entered into force. ${ }^{62}$ This Reform Act introduced the possibility for the model case parties to settle their dispute during the proceedings and have the OLG declare the settlement agreement binding for all pending cases. ${ }^{63}$ The individual claimants may opt out of the binding effect of the settlement and continue the stayed proceedings against the defendant in the individual proceedings before the LG. ${ }^{64}$

The KapMuG Act 2005 also introduced rules regarding the jurisdiction of KapMuG proceedings. In order to facilitate the effective management of the mass claims as well as to protect German domiciled companies against mass claims abroad, $\S 32 \mathrm{~b}$ was adopted in the German Civil Procedure Code (Zivilprozessordnung, ZPO). The competent court to bring damage claims for losses caused by false or misleading information disseminated on public capital markets is the court of the issuing company's seat. ${ }^{65}$ It is important to note that $\S 32 \mathrm{~b}$

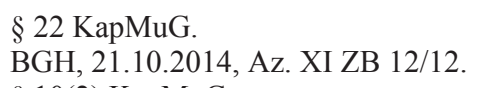

$\S 22 \mathrm{KapMuG}$.

BGH, 21.10.2014, Az. XI ZB 12/12.

$\S 10(2) \mathrm{KapMuG}$.

F. Reuschle, § 77, Deutsches und europäisches Bank- und Kapitalmarktrecht, p.1416.

$\S 2(2)(3)$ KapMuG as modified by Act of 30 June 2016 ( $\$ 16$ van Erstes Gesetz zur Novellierung von Finanzmarktvorschriften auf Grund europäischer Rechtsakte (1. FiMANoG) vom 30. Juni 2016 (BGB1. I S. 1514)). Violations by listed companies of their duty to disclose inside information to the public as required by the European Market Abuse Regulation (art. 17 of Regulation (EU) No 596/2014 of the European Parliament and of the Council of 16 April 2014 on market abuse (market abuse regulation) and repealing Directive 2003/6/EC of the European Parliament and of the Council and Commission Directives 2003/124/EC, 2003/125/EC and 2004/72/EC [2014] OJ L173/1) are brought under the material scope of the KapMuG.

${ }^{61} \S 1(1) \mathrm{KapMuG}$.

62 BGB1.I S.2182.

63 Deze mogelijkheid van opt-out verbindendverklaring is in deze herzieningswet opgenomen naar aanleiding van een advies aan het Bundesministerium der Justiz. Zie: Halfmeier/Rott/Feess 2010, pp.99-100.

$64 \S 23(3) \mathrm{KapMuG}$.

65 In accordance with $\S 5$ of the German Public Limited Company Act (Aktiengesetz), the company's seat is the place in Germany as provided for in the company's articles of association. For reason of court 
ZPO is only applicable to companies with a seat in Germany ${ }^{66}$ such that this jurisdiction rule is not in contravention with the jurisdiction rules laid down in the Brussels I/Brussels Ibis regulation. ${ }^{67}$ It is just an internal jurisdiction rule, not a private international law rule.

\subsubsection{Model Declaratory Proceedings (Musterfeststellungsverfahren)}

In July 2018, the German legislator adopted the model declaratory proceedings (Musterfeststellungsverfahren) in book 6 of the ZPO. ${ }^{68}$ Qualified consumer associations may file a collective declaratory claim regarding questions of law and fact common to claims of consumers against a business or company. ${ }^{69}$ The writ of summons must detail at least ten consumer claims. ${ }^{70}$ The issue may concern the (non-)existence of a legal relationship between a consumer and a business. ${ }^{71}$ In the case that at least 50 such claims are filed at the court registry $(\text { Klageregister })^{72}$ within two months registering the collective declaratory claim, the model declaratory proceedings will start. ${ }^{73}$ In the case that individual consumers brought claims to court in individual proceedings concerning the same matter before the collective declaratory proceedings were initiated, these consumers may register their claim on the basis of $\S 607$ $\mathrm{ZPO}$, and their individual proceedings are stayed. ${ }^{74}$

The declaratory judgment (Musterfeststellungsurteil) is published at the court registry. ${ }^{75}$ If a declaratory judgment can no longer be appealed, ${ }^{76}$ it is binding on all registered consumers and the defendant company. ${ }^{77}$ If the consumer has withdrawn his registration before this judgment, the latter has no binding effect. ${ }^{78}$

competence, the company's seat is situated at the place where the company is administered in the sense of $\S 17(1) \mathrm{ZPO}$.

${ }_{66} \S 32 \mathrm{~b}(1)$ last sentence ZPO. Furthermore, the wording of $\S 32 \mathrm{~b}$ ZPO does not indicate any requirement that German substantive law has to be applied in these cases. The 'normal' conflict of law rules are applicable. Cf. F. Mormann, 'Die Gerichtsstand-Dreifaltigkeit der ausschlie-ßlichen Zuständigkeit für Kapitalanlegerklagen nach § 32b ZPO' (2011) ZIP 25/26, pp.1187.

67 Explanatory Notes to the Act introducing the KapMuG (Begründung zu Gesetz zur Einführung von Kapitalanleger-Musterverfahren) BT-Drs 15/5091, p.13. It is important to note that art. 7(2) BrIbis reg does not only establish international jurisdiction regarding tort claims; it determines also which district court is competent to hear a case. Please note that in some particular circumstance the locus damni cannot be located in one particular district of a member state, so jurisdiction is conferred by the ECJ on the member state itself: cf. Löber case. It is up to the national courts to determine who has jurisdiction.

68 BGB1.I S.1151.

$69 \S 606(1)$ ZPO. Qualified consumer associations include non-German associations registered for at least four years at the European Commission on the basis of art. 4 of Directive 2009/22/EC of the European Parliament and of the Council of 23 April 2009 on injunctions for the protection of consumers' interests (Codified version) [2009] OJ L110/30, see § 606(2) ZPO.

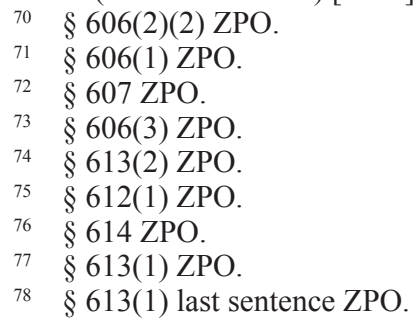


A settlement concluded between the association and the company needs court approval. ${ }^{79}$ Upon approval, it has binding effect on the consumer claims registered. ${ }^{80}$ Every consumer has the right to opt out of this settlement within one month after be notified of the court approval of the settlement. ${ }^{81}$

The structure of these model declaratory proceedings is similar to the Dutch collective proceedings in its declaratory nature. An important difference is that not all associations may file such a claim. Access to the Musterfeststellungsverfahren is restricted to officially recognised consumer associations. Like the KapMuG, it is an opt-in model. The binding effect of the declaratory judgment is limited to consumer claims registered.

Like the KapMuG Act, the Model Declaratory Proceedings Act 2018 included a jurisdiction rule as well. §32c ZPO confers exclusive jurisdiction to hear these claims to the court where the defendant is domiciled. As with $\S 32 \mathrm{~b} \mathrm{ZPO}$, this rule does not prevent the effective application of the Brussels Ibis regime, because it is not a rule of private international law but an internal jurisdiction matter.

\subsection{Dutch Collective Action Proceedings}

Under Dutch law, there are three procedural instruments to handle mass damage situations: first, the collective action proceedings enacted in 1994 in article 3:305a of the Dutch Civil Code; second, the Collective Settlement of Mass Damage Act 2005 (Wet Collectieve Afwikkeling Massaschade, WCAM); third, the preliminary reference to the Dutch Supreme Court procedure.

In a collective action procedure based on article 3:305a of the Dutch Civil Code (Burgerlijk Wetboek, BW), associations or foundations may file any claim except for individual damage compensation of the group members, ${ }^{82}$ as long as the claim is suitable to the bundled interest of the group of (legal) persons in whose interest the claim is filed. In mass damage cases, the association or foundation typically requests the court to give a declaratory judgment on the tortiousness of the defendant's behaviour towards the group of affected persons. In principle, all associations or foundations may initiate collective action proceedings irrespective of whether

\footnotetext{
§ 613(3) ZPO.

$\S 611(1) \mathrm{ZPO}$.

$\S 611(4) \mathrm{ZPO}$.
}

82 Art. 3:305a(3) BW. It is noteworthy to mention that a (private or public) body or organisation with registered office outside the Netherlands and placed on the list referred to in art. 4(3) Directive 98/27/EC may initiate an action for the protection of similar interests of other persons with their habitual residence in the country where the body or organisation is established, where the object of the organisation is to represent such collective interests or where the promotion of such interests has been entrusted to the public body (art 3:305c(1) BW). On the basis of art. 3:305c(2) BW, these organisations may institute the same actions, including requests for a declaratory judgment, as foundations or associations under art. 3:305a DCC. See: Breda District Court 10 July 2008, ECLI:NL:RBBRE:2008:BD6815, where it ruled that the UK Office of Fair Trading has legal standing and that it may institute other actions than an order requiring the cessation or prohibition of any intra-Community infringement of the EU consumer acquis as prescribed by the abovementioned Directive, because the Dutch legislator explicitly opted for a broad implementation of this Directive (para 4.2). Furthermore, this court also held that application of this procedure is not restricted to claims based on Dutch law. In this case, English law was applicable (paras 4.3-4.4). See also: Introductory Act of Directive 98/27/EC, Kamerstukken II 1998/99, 26 693, No. 3 (Explanatory Notes) p.8; p.3 respectively. 
these legal persons are registered outside the Netherlands..$^{83}$ The articles of the foundation or association have to state that it seeks the protection of similar interests of other persons. ${ }^{84}$ The statutory limitation period for the individual damage claims is suspended during the collective court proceedings. ${ }^{85}$

If the association and the defendants cannot reach a settlement after a declaratory judgment that the defendant behaved tortiously towards the group, the group members have to claim damages in individual normal court proceedings. The binding effect of judgments is limited to the parties to these proceedings. In collective action proceedings, those parties are the organisation and the defendant(s).

Since there is no scheme of compensation to adhere to by opt-in, the group members seeking compensation have to bring individual court proceedings. In principle the court in the individual damage claim proceedings is not bound by the judgment in the collective action proceedings about the defendant's behaviour towards the group members. However, it is highly unlikely that the courts' judgments will diverge. ${ }^{86}$ In the individual court procedures, the individual elements of causation, loss and fault on the part of the claimant will be in dispute. The individual facts and circumstances cannot be properly dealt with in a collective procedure. ${ }^{87}$

83 In its Explanatory Notes to the Dutch Introductory Act of Directive 98/27/EC (Kamerstukken II 1998/99, 26 693, No. 3, p.5), the Dutch legislator indicated that a non-Dutch consumer organisation has standing on the basis of art. 3:305a BW because it is not a condition that the association/foundation must be registered in the Netherlands.

${ }^{84}$ Art. 3:305a(1) BW.

85 The statutory limitation period of art. 3:310 BW regarding the individual claims is suspended by application of art 3:316 BW. Alkmaar District Court 22 April 2009, ECLI:NL:RBALK:2009:BI1927 para 4.2.5-4.2.6; Zutphen District Court 14 May 2009, ECLI:NL:RBZUT:2009:BI3783 (Consumentenbond/ Stichting Talpa) para 4.6. It is noteworthy that a qualifying association or foundation may also suspend the limitation period on the basis of art. 3:317 BW jo. art. 3:305a BW by sending the obligor a written notice on behalf of the entire group that the organisation reserves the right to performance of the obligor's obligations towards the individual members of the group. Dutch Supreme Court 28 March 2014, ECLI: NL:HR:2014:766 (VEB/Deloitte).

86 Dutch Supreme Court 27 November 2009, ECLI:NL:HR:2009:BH2162 (WorldOnline/VEB) para 4.8.2: 'Even though the judgment given in the present case has only the force of res judicata between on the one hand the VEB (Dutch Shareholders Association) and on the other hand World Online and/ or the banks, it is appropriate to take the decision on the tortiousness of the defendants' conduct given in these proceedings as a starting point in the individual follow-up proceedings.' The Dutch Supreme Court expressly addresses the normative effect of rulings in a test case proceeding concerning securities lease products. Dutch Supreme Court 5 June 2009 (De Treek/Dexia), ECLI:NL:HR:2009:BH2815, para 4.1: 'The case at hand concerns a dispute about a securities lease contract and it has been structured in cassation as a test case procedure. The purpose is to obtain binding precedent as wide as possible in other similar disputes. However, it must be instantly made clear that in ruling on disputes concerning securities lease products in individual cases one cannot deduce unlimitedly from the circumstances of the case, including, amongst others, the kind of product, the manner in which it was offered and the personal circumstances of the buyer. Nonetheless, the Supreme Court will, taking into consideration the aforementioned reservation and with a view to the practical, efficient and, if possible, uniform ruling on the large number of disputes concerning securities lease contracts, hereafter in a general observation deal with the relation between the duty of care and the award of damages in case of a breach of that duty of care. This ruling is not an instruction how to rule in future cases of this kind, but merely guidance given to the legal practice.'

87 In cases of collective damage claims, matters of causation, losses and own fault will have to be dealt with. Since, to a large extent these elements involve individual circumstances, the Dutch legislator 
Another form of collectivising claims related to third party financing is the bundling of individual claims. This is the most common form of 'collective' proceedings in cartel damage cases where the competitors seek damages of the infringer. ${ }^{88}$ The injured persons assign their individual claims to a single entity (mostly legal persons like a company). That entity will bring these individual claims to court. Therefore, the defendants' defences against each individual claim are not affected. ${ }^{89}$

The association or foundation and the defendant may reach a settlement before, during or after the collective action proceedings. Since 2005 the WCAM has provided the option to bind the injured persons in whose interest the collective action procedure was initiated. The WCAM provides for a judicial endorsement of a voluntary settlement agreement concluded between the alleged tortfeasor and representative organisations. Although the main focus of the Dutch legislator was on designing an efficient mechanism for the settlement of events causing mass personal injury (in particular cases, such as in $D E S^{90}$ ), it seems that the Act is of more practical relevance in securities litigation. Settlements were reached between the parties in the securities actions in the cases of Dexia, ${ }^{91}$ Vedior, ${ }^{92}$ Vie d'Or,${ }^{93}$ Shell, ${ }^{94}$ Converium,${ }^{95}$ DSB,${ }^{96}$ and Fortis,${ }^{97}$ all of these have been endorsed and declared binding by the Amsterdam Court of Appeal. The WCAM procedure has the following outline. A settlement contract is concluded between the alleged tortfeasor and an organisation representing the interests of the injured parties. In practice, a third party is included as well. The administrator - usually a foundation incorporated with the special purpose to distribute the settlement sum or fund - will execute the settlement and act as trustee of the settlement fund. The parties to the settlement contract jointly request, by petition, ${ }^{98}$ that the Amsterdam Court of Appeal declare the settlement binding on all persons to whom damage was caused. ${ }^{99}$ These interested persons are not summoned in this procedure but are given notice by letter or newspaper announcement. ${ }^{100}$ The court hears arguments of all interested parties. It can even allow for amendments to the settlement by the original parties. The court takes into consideration several points concerning the substantive and procedural fairness and efficiency of the settlement (such as amount of compensation and adequacy of the interested parties' representation). ${ }^{101}$ If the court deems these conditions met, it will declare the settlement contract binding upon all persons entitled to compensation under the settlement; by

deemed it impracticable to deal with these questions in a collective procedure. Parliamentary Papers II 1993/94, 22 486, No. 15 (Explanatory Notes to Amendment) p.1.

88 M.H.C. Sinnighe Damsté \& T.M.C. Arons, 'Collectief schadeverhaal bij kartels in de financiële sector; zegen of vloek', Ondernemingsrecht 2017/84.

89 Art. 6:145 BW.

90 Amsterdam Court of Appeal 1 June 2006, ECLI:NL:GHAMS:2006:AX6440.

91 Amsterdam Court of Appeal 25 January 2007, ECLI:NL:GHAMS:2007:AZ7033.

92 Amsterdam Court of Appeal 15 July 2007, ECLI:NL:GHAMS:2009:BI2717.

93 Amsterdam Court of Appeal 29 April 2009, ECLI:NL:GHAMS:2009:BI2717.

94 Amsterdam Court of Appeal 29 May 2009, ECLI:NL:GHAMS:2009:BI5744.

95 Amsterdam Court of Appeal 12 November 2010, ECLI:NL:GHAMS:2010:BO3908.

96 Amsterdam Court of Appeal 4 November 2014, ECLI:NL:GHAMS:2014:4560, JOR 2015/10.

97 Amsterdam Court of Appeal 13 July 2018, ECLI:NL:GHAMS:2018:2422.

98 Art. 1013(3) of the Dutch Code of Civil Procedure (Rechtsvordering, Rv).

99 Art. 7:907(1) BW.

100 Art. 7:1013(5) Rv.

101 Art. 7:907(3) BW. 
this declaration they become parties to the agreement. ${ }^{102}$ Individual interested parties are given the opportunity to opt out of the settlement. ${ }^{103}$

In 2012, the Dutch Act on a Preliminary Reference to the Dutch Supreme Court procedure was enacted. This procedure allows district courts to refer a question of law, which is crucially important and much debated between the parties, to the Supreme Court for an answer. The referred question has to be necessary to decide on the claim or petition at hand and it must be of direct importance to: (a) a multitude of claims which are based on the same or similar facts and which stem from the same or similar causes; or (b) the resolution or termination of many other disputes, originating in similar facts, in which the same question arises. ${ }^{104}$ Another important feature in regard to judicial economy is the power of courts that did not make a preliminary reference to the Supreme Court to suspend, upon request by one of the parties or ex officio, proceedings in which the answer on the preliminary reference is also of direct importance to decide on the claim or petition. When both parties wish to continue the proceedings, the court will not order suspension. ${ }^{105}$ An early answer to such a question of law by the Supreme Court may enhance the litigating parties' inclination to settle their dispute and prevent a possible unnecessary increase in litigation costs. The possibility of preliminary reference is not limited to two-party adversarial proceedings; it may be used in collective action proceedings as well.

At this moment it is not known when the new collective damage claim action procedure will enter into force. The bill was adopted by the Dutch Parliament's Lower House on 29 January $2019 .{ }^{106}$ One of the new features is the introduction of an exclusive representative organisation which will conduct exclusively the collective damage claim action procedure. ${ }^{107}$ The association or foundation has to adhere to stricter rules of corporate governance. ${ }^{108}$ After the court appoints the exclusive representative organisation, individual persons in whose interest the collective damage claim was filed may opt out individually within the term set by the court (at least one month). ${ }^{109}$ Court proceedings regarding damage claims for the same facts against the same defendant(s) as in the collective damage claim procedure are stayed for one year. ${ }^{110}$ If the organisation and the defendant(s) cannot reach a settlement, the court will determine a scheme of compensation based on the settlement proposals of those parties. ${ }^{11}$ The judgment in which the scheme is determined is binding on all group members unless they have opted out duly after the appointment of the exclusive representative organisation. ${ }^{112}$ Settlement reached during the procedure needs court approval. ${ }^{113}$ Group members have the option to opt out from this settlement and seek individual compensation. ${ }^{114}$

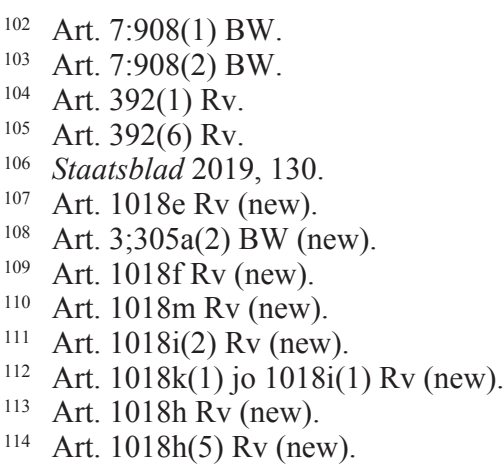




\section{JURISDICTION IN COLLECTIVE PROCEEDINGS UNDER THE BRUSSELS IBIS REGULATION}

\subsection{General Jurisdiction at Forum Rei}

On the basis of article 4 Brussels Ibis regulation, (legal) persons domiciled in a member state may, whatever their nationality, be sued in the courts of that member state (forum rei). Courts where the defendant is domiciled have as forum rei jurisdiction to hear collective claims irrespective of the claimant's domicile. It is an established principle in the case law of the European Court of Justice (ECJ) ${ }^{115}$ that in the scheme of the Brussels Ibis regulation, the relevant jurisdiction is that of the courts of the member state within the territory of which the defendant is domiciled. It is only by way of derogation from that principle that that regulation provides for an exhaustive list of cases (art. 5 BrIbis reg.) in which the defendant may or must be sued before the courts of another member state. ${ }^{116} \mathrm{~A}$ forum clause in a company's statutes binds its shareholders on the basis of article 25 Brussels I regulation. ${ }^{117}$ An issuer of securities can rely on the jurisdiction clause included in the prospectus against acquirers of those securities on the primary and the secondary market. ${ }^{118}$ In that regard the bundling of claims or the collective claim in their own right by representative organisations may be filed against the defendant irrespective of the domicile of the claimant of the underlying damage claims. The place where the alleged tortious behaviour by the defendant has to be situated and the place where the initial damages are sustained by the aggrieved party or parties are not determinant of this jurisdiction either.

Courts in the member states derive from the Brussels Ibis regulation their jurisdiction, in regard of these collective claims involving a jurisdiction of another member state, ${ }^{119}$ to hear

115 Its official name is 'Court of Justice of the European Union' (art. 13(1) Treaty on the European Union (TEU) since the entry into force of the Treaty of Lisbon ([2007]OJ C306/1). However, in English it is still most common to refer to this court as the European Court of Justice.

116 ECJ 14 February 2019 Case C-630/17, ECLI:EU:C:2019:123 (Milivojević/Raiffeisenbank St. Stefan-Jagerberg-Wolfsber eGen), para 81 referring to ECJ 25 January 2018 Case C 498/16, EU:C:2018: 37 (Schrems/Facebook Ireland Ltd) para 27.

117 Shareholders subscribing for shares in a company agree to be subject to all the provisions appearing in the statutes of that company, including a jurisdiction clause, and are bound by that clause provided that the statutes are lodged in a place to which the shareholder may have access, such as the seat of the company, or are contained in a public register. See ECJ 20 April 2016 Case C-366/13, ECLI:EU:C: 2016:282 (Profit Investment/Ossi), para 34. Shareholders are also bound by the amendments made to its statutes by the company's organs in accordance with the lex societatis and the statutes. See ECJ 10 March 1992, Case C-214/89, ECLI:EU:C:1992:115 (Duffryn/Petereit), para 27; ECJ 7 February 2013, Case C-543/10, ECLI:EU:C:2013:62 (Refcomp/Axa), para 31. For example, § 29 of Volkswagen AG's statutes provide that: 'The sole place of jurisdiction for all disputes between shareholders and of the beneficiaries or obligors of financial instruments relating to the Company's shares on the one hand, and the Company on the other, shall be the Company's domicile unless mandatory statutory provisions require otherwise. This also applies to disputes relating to compensation claimed for damage caused by false or misleading public capital market information, or the failure to provide such information. Foreign courts shall not have jurisdiction over such disputes.'

118 ECJ 20 April 2016 Case C-366/13, ECLI:EU:C:2016:282 (Profit Investment/Ossi), para 51.

119 This condition of cross-border involvement does not follow from the actual wording of art. 4 BrIbis reg., but from the Brussels Ibis regulation's purpose and nature of its origin. However, it is not required in all situations that one or more of the (formal) parties to the proceedings are domiciled in the 
claims against the defendant domiciled in their member state. ${ }^{120}$ Under the Brussels Ibis regime, companies or other legal persons or associations of natural or legal persons are domiciled at the place where they have their: (a) statutory seat; ${ }^{121}$ (b) central administration; or (c) principal place of business. ${ }^{122}$ So potentially, legal persons may be sued before three different courts.

The Brussels Ibis regulation applies in the case that the courts of the member state are addressed and the claim regards a civil or commercial matter not excluded by the regulation. ${ }^{123}$ Where the collective claim regards civil or commercial matters without any involvement of the jurisdiction of another member state, national courts have to establish jurisdiction for claims against the company or other legal person based on their own respective procedural and private international rules. Depending on whether the siège réel or statutory seat doctrine is adhered to by the lex fori, companies or other legal persons will be domiciled at the place of central administration and/or business or at the place where the company is registered, that is, where its statutory seat is situated. ${ }^{124}$

\subsection{Special Jurisdiction}

Collective action claims may also be brought before courts in member states other than the defendant's domicile. In order to determine this question of jurisdiction the following provisions are important. The general rules of international jurisdiction in all (former) European acts or legislation (Brussels Convention, ${ }^{125}$ Brussels I regulation, ${ }^{126}$ Brussels Ibis regulation) adopted as a guiding principle that the rules of jurisdiction should be highly predictable, ${ }^{127}$ and that alternative grounds of jurisdiction should be based on a close connection between the court and the action or in order to facilitate the sound administration of justice. ${ }^{128}$ The requirement of a close connection should ensure legal certainty and avoid the possibility of the defendant being sued in a court of a member state which he could not reasonably have fore-

member state of the court addressed. It suffices that the dispute is (partially) situated in another member state than the forum's. Cf. Tekst \& Commentaar Rv (Ibili), comm. art. 4 Brussel I-bis, par 1.

120 Art. 2 jo. art. 63(1) BrIbis reg.

121 For the purposes of Ireland, Cyprus and the United Kingdom, 'statutory seat' means the registered office or, where there is no such office anywhere, the place of incorporation or, where there is no such place anywhere, the place under the law of which the formation took place. See art. 63(2) BrIbis reg.

122 Art. 63(1) Brlbis reg.

123 Art. 1 BrIbis reg.

124 Please note that the Undroit Convention on Substantive Rules for Intermediated Securities (Geneva Securities Convention) also does not contain conflict of law rules determining which law applies to the issuing company in order to ascertain which shareholder, bondholder or other person is entitled to receive and exercise the rights attached to the securities, or to recognise for any other purpose. The connecting factor is determined by the lex societatis, the law applicable to the relatitonship between the shareholder and the issuing company. Cf. P.-H Conac, U. Segna and L. Thévenoz, Intermediated Securities, The Impact of the Geneva Securities Convention and the Future European Legislation (CUP) 2013, p.112.

${ }_{125} 1968$ Brussels Convention on jurisdiction and the enforcement of judgments in civil and commercial matters [1972] OJ L299/32; and last consolidated version: [1998] OJ C27/1.

126 Council Regulation (EC) No 44/2001 of 22 December 2000 on jurisdiction and the recognition and enforcement of judgments in civil and commercial matters [2001] OJ L12/1.

127 Recital 15 of the Preamble to the Brussels Ibis regulation.

128 Recital 16 of the Preamble to the Brussels Ibis regulation. 
seen. ${ }^{129}$ All three European acts of legislation provide for special jurisdiction in typical cases where the legislator deemed there to be a close connection and/or a need to facilitate a sound administration of justice.

First of all, it should be noted that the special jurisdiction provisions to be discussed in this subparagraph do not specifically provide for a concentration of claims. There is only one specific provision that achieves a concentration of claims. Article 8(1) Brussels I regulation offers claimants, under certain circumstances, the possibility to sue several defendants, domiciled in different member states, in the courts of the place where any one of them is domiciled. A condition to concentrate claims against multiple defendants for the forum rei of one of them is that the claims are so closely connected that it is expedient to hear and determine them together to avoid the risk of irreconcilable judgments resulting from separate proceedings. ${ }^{130}$ In order for judgments to be regarded as irreconcilable, it is not sufficient that there be a divergence in the outcome of the dispute, but that divergence must also arise in the same situation of fact, ${ }^{131}$ as well as of law. ${ }^{132}$ The ECJ ruled that this concentration is not precluded solely because actions against several defendants for substantially identical copyright infringements are brought on national legal grounds varying according to the member states concerned. ${ }^{133}$ There is no inherent risk of irreconcilable judgments if the claims arising from (a) substantially identical event(s) are subject to different laws. Courts have to assess, in the light of all the elements of the case, whether there is a risk of irreconcilable judgments if those actions were determined separately. Connection is more easily adopted if the national laws on which the actions against the various defendants are based are substantially identical. ${ }^{134}$ The concentration at the forum connexitatis may play an important role in concentrating claims against multiple defendants. ${ }^{135}$ The focus of this chapter is however the concentration of claims on the claimant's side, that is, the possibility to initiate collective action proceedings in the interest of a group of persons allegedly affected by a common defendant's behaviour.

In this subsection, special attention is given to the forum delicti of article 7(2) Brussels Ibis regulation. Article 7(1) Brussels Ibis regulation provides special jurisdiction in matters relating to a contract at the courts of the place where the obligation in question should be performed. Collective claims in contractual matters can only be concentrated at the latter forum if all of the contracts of persons in whose interest the collective claim was initiated are to be performed at that single place of the forum. Given the fact that the Brussels Ibis regulation does not only

129 Recital 16 of the Preamble to the Brussels Ibis regulation.

130 For a critical reflection on the different interpretations by the ECJ on this condition, refer to A. Dickinson and E. Lein, The Brussels I Regulation Recast (OUP) 2015, p.188.

131 Please note that the ECJ has not yet ruled on the requirement of 'same situation of fact'. According to A-G Vlas in his Conclusion of 11 January 2019, in case 17/05852 before the Dutch Supreme Court (ECLI:NL:PHR:2019:123), it is not required that the claims against the defendants have an identical factual basis as long as it was foreseeable for the defendant that claims could be brought against him before the court of his codefendant, which is unlikely if he acted independently from his codefendant (para 3.7).

132 ECJ 11 October 2007, Case C-98/06, ECLI:EU:C:2007:595 (Freeport/Arnoldsson), para 40.

133 ECJ 11 October 2007, Case C-98/06, ECLI:EU:C:2007:595 (Freeport/Arnoldsson), para 41, 47; ECJ 1 December 2011 Case C-145/10, ECLI:EU:C:2011:798 (Painer/Standard VerlagsGmbH), para $80-81$.

134 ECJ 1 December 2011 Case C-145/10, ECLI:EU:C:2011:798 (Painer/Standard VerlagsGmbH), para 82.

135 S.J. Schaafsma, 'Multiple defendants in intellectual property litigation' (2016) NIPR, pp.696-705. 
provide international competence in the narrow sense of one particular national jurisdiction, but provides specific competence to the place of performance of the contractual obligations, the consolidation or collectivisation of contractual claims could be narrow if different places of performance apply to the individual claims of group members.

On the basis of article 7(2) Brussels Ibis regulation, ${ }^{136}$ a $\left(\right.$ legal $\left.{ }^{137}\right)$ person domiciled in a member state may be sued in another member state, in matters relating to tort, delict or quasi-delict, in the courts of the place where the harmful event occurred or may occur.

The ECJ held in the $C D C$ case that a consolidation of a number of potential claims for damages does not provide the assignee with any other competent forum than the original owner of the claim had. So a claim vehicle to which the individual damage claims had been assigned is confronted from the outset with the fact that the transfer of claims by the initial creditor cannot, by itself, have an impact on the determination of the court having jurisdiction under article 7(2) Brussels Ibis regulation. According to the ECJ in CDC, it follows that the location of the harmful event must be assessed for each claim for damages independently of any subsequent assignment or consolidation. ${ }^{138}$ Furthermore, the ECJ noted that article 7(2) Brussels Ibis regulation must be interpreted independently and strictly. ${ }^{139}$

Under the Brussels Convention the ECJ ruled in 1976, in the famous Bier/Mines de Potasse case, ${ }^{140}$ that the claimant may choose between two competent courts as forum delicti: the court of the place where the tortious behaviour was allegedly committed by the defendant (Handlungsort) and the court of the place where the initial damage was allegedly directly sustained by the aggrieved party (Erfolgsort). This choice between forum delicti commissi and forum damni is only available if the jurisdiction where the alleged tortious behaviour was committed was different from the jurisdiction where the initial damages were allegedly directly manifesting in objects, persons or other property rights.

In some jurisdictions (France and the Netherlands), collective action proceedings are two-staged. First of all, the courts rule on the liability of the defendant vis-à-vis the group in whose interest the collective claim was filed. Second, the damage claims will be (at an individual or a collective/aggregated/categorised level) assessed by the courts. Concerning the question of international jurisdiction regarding the declaratory (interim) judgment, the ECJ held in the Henkel and DFDS Torline/SEKO cases that it is not possible to accept an interpretation of Article 5(3) of the Brussels Convention according to which application of that provision is conditional on the actual occurrence of damage. Likewise, it has held that the finding that the courts for the place where the harmful event occurred are usually the most appropriate for deciding the case, in particular on the grounds of proximity and ease of taking evidence, is equally relevant whether the dispute concerns compensation for damage which has already

136 Art. 5(3) BrI reg (repealed)/art. 5(3) Brussels Convention (repealed).

137 For the purposes of the Brussels Ibis regulation, a company or other legal person or association of natural or legal persons is domiciled at the place where it has its: (a) statutory seat; (b) central administration; or (c) principal place of business (art. 63(1) BrIbis reg). In the case that one of these connecting factors is situated in a member state of the EU, the company or other legal person may be sued before the forum loci delicti or the forum loci damni if the claimant alleges that the company acted unlawfully at that place or he incurred direct losses at that place respectively.

138 ECJ 21 May 2015 Case C-352/13, ECLI:EU:C:2015:335 (CDC/Degussa) para 36.

139 ECJ 21 May 2015 Case C-352/13, ECLI:EU:C:2015:335 (CDC/Degussa) para 37, referring to ECJ 28 January 2015 Case C-375/13, ECLI:EU:C:2015:37 (Kolassa/Barclays) para 43.

140 ECJ 30 November 1976 Case C-21/76, ECLI:EU:C:1976:166 (Bier/Mines de Potasse). 
occurred or relates to an action seeking to prevent the occurrence of damage. ${ }^{141}$ It follows from the foregoing that Article 5(3) of the Brussels Convention must be interpreted as meaning that a case concerning the legality of industrial action, in respect of which exclusive jurisdiction belongs - in accordance with the law of the Contracting State concerned - to a court other than the court which has jurisdiction to try the claims for compensation for the damage caused by that industrial action, falls within the definition of 'tort, delict or quasi-delict'.

\subsubsection{Forum damni: initially sustained loss}

It is established case law that only the court of the place where the claimant allegedly suffered its initial damage has jurisdiction as forum loci damni. ${ }^{142}$ This line of ruling was confirmed by the European Court of Justice in the Marinari case. The facts of that case were the following.

In April 1987, Marinari lodged with a Manchester branch of Lloyds Bank a bundle of promissory notes with a face value of USD $752,500,000$. These promissory notes were issued by the Negros Oriental province of the Republic of the Philippines in favour of Zubaidi Trading Company of Beirut. After opening the envelope, Lloyds' staff refused to return the promissory notes and informed the English police of their doubts regarding the origin of these notes. Subsequently Marinari was arrested and the promissory notes sequestrated by the police.

Finally, Marinari was released by the English judicial authorities. Marinari sued Lloyds Bank at the district court of Pisa, his domicile, demanding (a) compensation for damages caused by his arrest as a result of its staff's conduct (breach of several contracts and damage to his reputation) and (b) payment of the face value of the promissory notes.

In Marinari, the ECJ ruled that the Erfolgsort does not cover every place where the victim claims to have suffered financial damage following upon initial damage arising and suffered by him in another member state. ${ }^{143}$ Financial damages suffered as a loss consequential of another loss incurred does not provide jurisdiction in the sense of the Brussels Ibis regulation. ${ }^{144}$ In this case, the initial damages (arrest and refusal of payment) were incurred by Marinari in Manchester; the financial damages or pure economic losses (breach of contract and reputation) were suffered or incurred by him consequent to these initial damages. For that reason, the district court of Pisa does not have jurisdiction as forum loci damni. Article 7(2) Brussels Ibis regulation does not provide jurisdiction for the forum where consequential financial damage or derived financial damage was incurred by the claimant.

\subsubsection{Forum damni: initially sustained pure economic loss}

Because of this established case law that only courts of places where the claimant allegedly suffered its losses initially have jurisdiction as forum loci damni, the question arises as to whether courts may establish jurisdiction as Erfolgsort in the case that the initial (that is, nonconsequential) damage is purely financial. (Please note that pure economic loss and pure

141 ECJ 5 February 2004 Case-C-18/02, ECLI:EU:C:2004:74 (DFDS Torline/SEKO) para 27-28; ECJ 1 October 2002 Case C-167/00, ECLI:EU:C:2002:555 (VKI/Henkel) paras 46; 48.

142 ECJ 30 November 1976 Case C-21/76, ECLI:EU:C:1976:166 (Bier/Mines de Potasse) para 11, ECJ 11 January 1990 Case C-220/88, ECLI:EU:C:1990:8 (Dumez France and Tracoba/Hessische Landesbank) para 17, and ECJ 7 March 1995 Case C-68/93, ECLI:EU:C:1995:61 (Shevill/Presse Alliance) para 19.

143 MünchKommZPO/Paulus, Bd 3, art. 7 VO(EU) Nr. 1215/2012, Rdn 199.

144 ECJ September 1995 Case C-364/93, ECLI:EU:C:1995:289 (Marinari/Lloyd's Bank plc) paras $14-15$. 
financial damage are used interchangeably.) If so, where should this place of initial financial damage be located under the Brussels Ibis regime?

In the few cases that have been brought to the European Court of Justice, the financial losses were initially incurred by investors as a result of misleading statements by share or bond issuing companies. Damages are suffered by the investors as a result of the misleading nature of these statements being revealed and the share or bond prices falling. In these cases the corporate misinformation may be contained in a prospectus or in ad hoc statements to the financial markets.

The ECJ's rulings in the case of Kronhofer, ${ }^{145}$ as well as that of Kolassa, ${ }^{146}$ were interpreted by legal scholars as indicating that financial losses initially suffered by investors were situated at the bank accounts or securities accounts. ${ }^{147}$ These accounts were deemed as connecting factor to determine the fori loci damni in the sense of the Brussels Ibis regulation. ${ }^{148}$ The Austrian connection in these cases is irrefutable.

Kronhofer was an investor domiciled in Feldkirch, Austria. He transferred USD 82,500 from his Austrian current account to an investment account with Protectas Vermögensverwaltungs $\mathrm{GmbH}$ in Germany. This amount was used to subscribe to highly speculative call options on the London Stock Exchange. As a result of this transaction, Kronhofer suffered losses and was repaid only partially on the capital invested by him.

The ECJ ruled in 2004 that the district court of Feldkirch does not have international jurisdiction, because Kronhofer suffered his financial damages as a consequence of the financial damages initially sustained in Germany. In this case the financial damages sustained in Austria were consequential to the damages initially sustained in Germany. The losses incurred at the place where Kronhofer's assets were concentrated and where he was domiciled were the result of losses incurred in Germany where part of his assets were located, among others his investment account at Protectas.

145 ECJ 10 June 2004 Case C-168/02, ECLI:EU:C:2004:364 (Kronhofer/Maier).

146 ECJ 28 January 2015 Case C-375/13, ECLI:EU:C:2015:37 (Kolassa/Barclays).

147 Annotation by O. Boskovic bij Kolassa-arrest in Revue critique de droit international privé (2015), p.921; A. Cottiga, 'I.A. Régulation européenne. C.J.U.E., 28 Janvier 2015, Harald Kolassa c. Barclays Bank PLC, Aff. C-375/13', Revue Internationale des Services Financiers (2015) n 02 pp.40-49, p.45; R. Freitag, 'Internationale Prospekthaftung revisited - Zur Auslegung des europäischen Kollisionsrechts vor dem Hintergrund der 'Kolassa"-Entscheidung des EuGH', Wertpapier-Mitteilungen (WM) (2015), p.1166; M. Gargantini (2016), 'Capital Markets and the Market for Judicial Decisions: In Search of Consistency', MPILux Working Paper 1, via www.mpi.lu, pp.14-15; Andrew Dickinson and Eva Lein (eds), The Brussels I Regulation Recast (Oxford University Press) 2015, § 4.108, p.168; Annotation by J. von Hein to Kolassa judgment, Juristen Zeitung (JZ) (2015) 19, p.948-9 ; J. von Hein, Art. 4 Rome II Regulation, in: G.P. Caliess (ed.), Rome Regulations, Commentary, 2nd edn. (Wolter Kluwer Law \& Business) 2015, p.507; M. Müller, 'EuGVVO: Gerichtsstand für Schadensersatzklage eines Verbrauchers wegen Wertverlust einer Finanzinvestition', Europäische Zeitschrift für Wirtschaftsrecht (EuZW) (2015) 218, Rdn 57; B. Steinrötter, 'Der notorische Problemfall der grenzüberschreitenden Prospekthaftung, Zugleich Besprechung von EuGH, RIW 2015, 144 - Kolassa', Recht der internationalen Wirtschaft (RIW) (2015), p.411.

${ }_{148}$ M. Haentjes and D.J. Verheij, 'Waar zijn de effecten? Lokaliseren van vermogensschade na Kolassa', $A V \& S$ (2015), p.26; Vlas in his annotation to ECJ 10 June 2004 Case C-168/02, ECLI:EU: C:2004:364 (Kronhofer/Maier) in NJ 2006/335, para 4; Strikwerda in his annotation to ECJ 28 January 2015 Case C-375/13, ECLI:EU:C:2015:37 (Kolassa/Barclays) in NJ (2015) 332, para 7. Cf. A-G Jääskinen in his Conclusion of 29 November 2012 in Case C-228/11, ECLI:EU:C:2012:766 (Melzer/MF Global UK Ltd), para 32. 
In the Kolassa case, the ECH held on 28 January 2015 that international jurisdiction based on article 7 lid 2 Brussels Ibis regulation may be assumed by the courts where the claimant is domiciled, on the basis of the place where the loss occurred, to hear and determine such an action, particularly when the alleged damage occurred directly in the applicant's bank account held with a bank established within the area of jurisdiction of those courts. ${ }^{149}$

After rejecting the claimant's domicile in Kronhofer, the ECJ in Kolassa seemed to rule that pure financial losses have to be situated at the place where that specific asset affected by the tortious act of the defendant was located..$^{150}$

As mentioned, there was a general understanding that these rulings in Kronhofer and Kolassa established the jurisdiction as Erfolgsort for courts of the district where the bank was situated if the initial damages were directly sustained by the claimant on his or her bank account.

\subsubsection{Universal Music}

On 16 June 2016 the ECJ ruled in the Universal Music case. ${ }^{151}$ In that case, purely economic losses were incurred by Universal Music, a Dutch company established in the Netherlands, as a result of Czech lawyers' occupational failure in a transaction transferring the shares in the Czech company B\&M to Universal Music. The archetypical typing error resulted in Universal Music paying a price superior to the agreed price. After an arbitration procedure in the Czech Republic, Universal Music concluded a settlement. The settled sale price due to the selling shareholder in B\&M and the arbiters' fee were paid by Universal Music from a bank account held in Baarn, the Netherlands. Subsequently, Universal Music sued its Czech lawyer for damages at the district court of Utrecht.

Jurisdiction was declined by the Utrecht District Court, ${ }^{152}$ as well as the Arnhem-Leeuwarden Court of Appeal, ${ }^{153}$ because nearly all elements of the case - except for the current or payment account at the Dutch bank - were situated in the Czech Republic. The settlement sum was paid from Universal Music's current account held at the bank in the Netherlands. The Dutch Supreme Court referred to the ECJ the question whether article 7(2) Brussels Ibis regulation is to be interpreted as meaning that the 'place where the harmful event occurred' can be construed as being the place in a member state where the damage occurred, if that damage consists exclusively of financial damage which is the direct result of unlawful conduct occurring in another member state. ${ }^{154}$

The ECJ answered this question negatively. It held that pure financial damage occurring directly in a claimant's bank account cannot, in itself, be qualified as a 'relevant connecting factor', pursuant to article 7(2) Brussels Ibis regulation. In this particular case, the ECJ observed that a company such as Universal Music may have had the choice of several bank accounts from which to pay the settlement amount, so that the place where that account is situated does not necessarily constitute a reliable connecting factor. Therefore, it is only where the other circumstances specific to the case also contribute to attributing jurisdiction to the courts

149 ECJ 28 January 2015 Case C-375/13, ECLI:EU:C:2015:37 (Kolassa/Barclays), para 55; 57.

150 MünchKommZPO/Paulus, Bd 3, art. 7 VO(EU) Nr. 1215/2012, rdn 203.

151 ECJ 16 June 2016, Case C-12/15, ECLI:EU:C:2016:449 (Universal Music).

152 Utrecht District Court 27 May 2009, ECLI:NL:RBUTR:2009:BI5081.

153 Arnhem-Leeuwarden Court of Appeal 15 January 2013, ECLI:NL:GHARL:2013:BY8880.

154 Dutch Supreme Court 9 January 2015, ECLI:NL:HR:2015:36; OJ [2015] C 89/12. 
for the place where a purely financial damage occurred that such damage could, justifiably, entitle the applicant to bring the proceedings before the courts for that place. ${ }^{155}$

The ECJ seemed to interpret the situated place where the direct damages were incurred in the Czech Republic. There, Universal Music's payment obligation was incurred by the arbitration panel's ruling. The fact that Universal Music paid the sum due from its payment account held at a bank in the Netherlands was not important. ${ }^{156}$ Another relevant circumstance and difference between Kolassa and Universal Music is the timing of loss awareness by the claimant. This is important in light of the ECJ's overall objective to prevent forum shopping by the claimant. In Kolassa, the claimant was unaware of his losses as soon as he transferred the purchase price for the certificates from his payment account. Hence, the bank account as relevant connecting factor to determine the Erfolgsort could not be manipulated by the claimant because he was at that moment unaware of his loss inflicting transaction. In Universal Music, the claimant knew the settlement sum due and could, by choosing a particular payment account from which to transfer the money, create a forum favourable for his claim against the Czech law firm. ${ }^{157}$ The ECJ ruled therefore specifically that as a consequence,

purely financial damage which occurs directly in the applicant's bank account cannot, in itself, be qualified as a 'relevant connecting factor', pursuant to Article 5(3) of Regulation No 44/2001 [art. 7(2) Brussels I regulation]. In that respect, it should also be noted that a company such as Universal Music may have had the choice of several bank accounts from which to pay the settlement amount, so that the place where that account is situated does not necessarily constitute a reliable connecting factor. $^{158}$

The question is whether the Universal Music judgment has to be interpreted as an affirmation of the ECJ's judgment in the Marinari case. ${ }^{159}$ Is the payment of the settlement sum set by an arbitration panel in the Czech Republic direct financial damage, indeed ${ }^{160}$ The former A-G at the Dutch Supreme Court, Strikwerda, presumed in his annotation that the ruling given by the ECJ must be interpreted as seeking to establish that there is no real divergence between Handlungsort and Erfolgsort in case there is just one relevant aspect of the damage must be situated at the Handlungsort, regardless of whether all other aspects point to another place. There is only an independent Erfolgsort if all relevant aspects of the directly incurred financial damage can be situated in another member state than the member state in which the unlawful act was committed.

155 ECJ 16 June 2016 Case C-12/15, ECLI:EU:C:2016:449 (Universal Music), par 38-39.

156 MünchKommZPO/Paulus, Bd 3, art. 7 VO(EU) Nr. 1215/2012, rdn 203.

157 See MünchKommZPO/Paulus, Bd 3, art. 7 VO(EU) Nr. 1215/2012, rdn 203.

158 Para 38.

159 See ECJ 16 June 2016 Case C-12/15, ECLI:EU:C:2016:449 (Universal Music) para 34 expressly referring to the central ruling of Marinaro, that "the term "place where the harmful event occurred" may not be construed so extensively as to encompass any place where the adverse consequences of an event, which has already caused damage actually arising elsewhere, can be felt (judgment of 19 September 1995 in Marinari, C-364/93, EU:C:1995:289, paragraph 14)'.

160 ECJ 16 June 2016 Case C-12/15, ECLI:EU:C:2016:449 (Universal Music), para 31: 'The damage for Universal Music resulting from the difference between the intended sale price and the price mentioned in that contract became certain in the course of the settlement agreed between the parties before the arbitration board, in the Czech Republic, on 31 January 2005, the date on which the actual sale price was fixed. Therefore, the obligation to pay placed an irreversible burden on Universal Music's assets.' 
Strikwerda concludes that as a consequence of the Universal Music ruling the court of the Erfolgsort can from now on only derive jurisdiction from circumstances other than the fact that financial damage occurred directly at the bank account. ${ }^{161}$ The habitual residence of the claimant qualifies as such circumstance. ${ }^{162}$

Furthermore, it is important to note that, as Mankowski stated in his annotation to the ECJ's Universal Music judgment, claimants have legal interests (Rechtsgut) situated in multiple jurisdictions. ${ }^{163}$ The forum loci damni is determined by the place where the directly/primarily affected specific legal interest is situated. It is important that the ECJ clearly recognises that claimants may have legal interests situated in multiple jurisdictions. It is important to recognise that not all their assets that can be directly affected are situated in the same jurisdiction. Depending on their specific claim they may seek compensation for the direct consequences of the defendant's tortious behaviour on a specific legal interest situated in a particular member state. Therefore, the courts addressed by a particular compensation claim involving directly suffered financial damage have to methodically determine the place where the legal interest that the substantive law applicable to the claim seeks to protect must be situated. ${ }^{164}$

\subsubsection{Löber case and beyond}

In yet again an Austrian case, the ECJ was asked to rule again on financial losses directly incurred in a member state as result of alleged misconduct in another member state. In the Löber case, the Supreme Court of Austria (Oberster Gerichtshof, OGH) referred to the ECJ the question whether courts of the place where direct financial damage are sustained, can derive their jurisdiction from article 7(2) Brussels Ibis regulation in the case that noncontractual

161 Annotation of Strikwerda in NJ 2018/39, para 7.

162 Annotation of Strikwerda in NJ 2018/39, para 9.

163 EuZW 2016, 583: 'Das doppelte “unmittelbar" (Rn. 40) ist nur vor dem Hintergrund der bisherigen Rechtsprechungerklärlich. Dass sich der Schaden "unmittelbar auf einem Bankkonto" des Opfers niedergeschlagen habe, stammt aus Kolassa (EuGH, ECLI:EU:C:2015:37 = EuZW 2015, 218). Dagegen stammt die "unmittelbare Folge eines unerlaubten Verhaltens" aus Dumez France (EuGH, ECLI:EU:C:1990:8 = EuZW 1990, 34 [Rs. C-220/88]) und Marinari (EuGH, ECLI:EU:C:1995:289 $=E u Z W$ 1995, 765 [Rs. C-364/93]), geboren aus der an sich richtigen Ausgrenzung bloß mittelbarer Folgeschäden (vgl. GA Szpunar, ECLI:EU:C:2016:161 = BeckRS 2016, 80680 Rn. 35 - Schlussanträge Universal Music). Um eine Umschreibung des vom konkreten Delikt primär geschützten Rechtsguts bemüht sich der EuGH aber nicht. Darin liegt die Crux der Entscheidung.'

164 P. Mankowski in EuZW 2016, 583: 'Erstens stellt er nicht klar genug heraus, dass es für den relevanten Schaden auf die Verletzung des primär geschützten Rechtsguts ankommt. Er identifiziert nämlich das im konkreten Fall primär geschützte Rechtsgut nicht. Dazu müsste man ermitteln, welcher Deliktstatbestand aus welchem nationalen Recht einschlägig ist und welches Rechtsgut er schützt (Mankowski in Magnus/Mankowski, aaO, Art. 7 Brussels I Regulation Rn. 320). An dieser Stelle kommt man an einer Vorfrage mit IPR-Anwendung der Rom II-VO auch beim Deliktsgerichtsstand nicht vorbei (entgegen EuGH, ECLI:EU:C:1995:289 = EuZW 1995, 765 Rn. 18 f. - Marinari; Cassaz., Riv. dir. int. priv. proc. 2004, 1372 [1374]). Universal Music zeigt die Kalamitäten, in die man gerät, wenn man anders und damit nicht methodisch genug vorgeht. Zweitens kommt es, wenn das Vermögen primär geschütztes Rechtsgut ist, auf das jeweils konkret betroffene Teilvermögen des Opfers an, sofern das Opfer mehrere unterscheidbare Vermögensmassen an mehreren verschiedenen Orten hat. Bei Bankkonten ist der erste Transfer nach außen an Dritte entscheidend (Corneloup, Rev. crit. dr. int. pr. 103 [2014], 438 [441]; Müller, EuZW 2015, 218 [223 f.]; Mankowski in Magnus/Mankowski, aaO, Art. 7 Brussels I Regulation Rn. 330). Der zweite Satz in Rn. 38 geht immerhin in diese Richtung. Reinen Durchgangskonten kommt hier keine Bedeutung zu (Lehmann, [2011] 7 JPrIL 527 [544]).' 
claims are based on prospectus liability. ${ }^{165}$ In this case Löber took her investment decision on the basis of an alleged misleading prospectus at the place where she was domiciled. Furthermore, on the basis of that decision, she transferred the purchase price for the security acquired on the secondary market from her account held with an Austrian bank to a clearing account held with another Austrian bank, from where the purchase price was subsequently transferred to the seller. The ECJ ruled that directly incurred financial damage may establish jurisdiction, and the OGH submitted several connecting factors to determine Erfolgsort jurisdiction: (a) investor's domicile; (b) the seat of the accountkeeping branch of the bank from which the amount invested was transferred to the clearing account; (c) the seat of the accountkeeping branch of the bank keeping the clearing account; or (d) a choice for the claimant from (a) to (c).

First of all, the ECJ affirmed its ruling in Universal Music. ${ }^{166}$ Thereafter, it held that as a whole, the specific circumstances of the Löber case contribute to attributing jurisdiction to the Austrian courts. The following circumstances were deemed relevant by the ECJ. Löber is domiciled in Austria. All payments related to the investment transaction were made from Austrian bank accounts, namely the personal bank account and clearing accounts intended for the execution of that transaction. Löber acquired the certificates - bearer bonds issued by the defendant Barclays Bank plc to institutional investors ${ }^{167}$ - on the Austrian secondary market. The information about these certificates was provided to her in a prospectus notified at the Österreichische Kontrollbank, the notification office designated in the Austrian Capital Markets Act. ${ }^{168}$ On the basis of this information, Löber signed the purchase contract. Thereby she lost or definitively reduced her assets, because the money paid for those certificates was used in a pyramid scheme and the certificates themselves were worthless. ${ }^{169}$ The ECJ deemed the conferring jurisdiction as Erfolgsort in these circumstances, consistent with the objectives of predictability and proximity. ${ }^{170}$

With express reference to its ruling in Kolassa, the ECJ concluded that, given that the issuing bank allegedly not complying with its legal prospectus obligations must, when it decides to notify the prospectus relating to that certificate in other member states, anticipate that inadequately informed operators, domiciled in those member states, might invest in that certificate and suffer damage. As a result, the objective of Brussels Ibis regulation, strengthening the legal protection of persons established in the EU by enabling a claimant to identify easily the court in which he may sue and the defendant reasonably to foresee in which court he may be sued, is met by upholding the place where the bank is established in which the applicant possessed the bank account in which the reduction occurred, as the place where the damage occurred. ${ }^{171}$

165 OGH 10.05.2017, 3Ob28/17i, ECLI:AT:OGH0002:2017:0030OB00028.17I.0510.000 and ECLI: AT:OGH0002:2017:RS0131405; Request filed in Case C-304/17 (Löber/Barclays Bank) [2017] OJ C269/6.

166 ECJ 12 September 2018, Case C-304/17, ECLI:EU:C:2018:701 (Löber/Barclays Bank) para 30.

167 ECJ 12 September 2018 Case C-304/17, ECLI:EU:C:2018:701 (Löber/Barclays Bank) paras 6-7.

$168 \S 12$ Kapitalmarktgesetz (KMG).

169 Para 9; para 33.

170 Recitals 11 and 12 of the Preamble to the Brussels Ibis regulation.

171 ECJ 12 September 2018, Case C-304/17, ECLI:EU:C:2018:701 (Löber/Barclays Bank) para 35 referring to ECJ 28 January 2015 Case C-375/13, EU:C:2015:37 (Kolassa), para 56. 


\subsection{Future Developments}

The first Dutch court confronted with the implications of the Universal Music judgment was the Amsterdam District Court. In summary, the Dutch investors' association VEB acts in the interest of BP investors incurring direct financial losses on their securities account as a result of BP's alleged violation of its duty to disclose inside information to the market. Furthermore, VEB alleged that BP misled the market in regard of the implications of the Deepwater Horizon scandal in the Gulf of Mexico. Investors suffered losses due to a fall in BP's share price. The district court declined jurisdiction by reference to the ECJ's ruling in Universal Music. The mere fact that financial losses were incurred at a bank account is insufficient to establish jurisdiction on the basis of article 7(2) Brussels I regulation. This ruling was upheld by the Amsterdam Court of Appeal. This court deemed it irrelevant that BP turned to a worldwide investor community to promote its shares. Furthermore, it declined the relevance of the fact that VEB acted in the interest of BP investors domiciled in the Netherlands. These circumstances were not considered sufficient to establish jurisdiction as Erfolgsort in order to facilitate sound administration of justice.

This case was dealt with in cassation by the Dutch Supreme Court. The central question in this procedure was whether the ECJ in Kronhofer, Kolassa and Universal Music adopted the line that article 7(2) Brussels Ibis regulation provides jurisdiction to the court of the place where the claimants allegedly incurred direct financial losses on their bank account (current and investment account) and where the claimant is domiciled. On the advice of Advocate-General Vlas, the Dutch Supreme Court referred the following preliminary questions to the ECJ in its judgment of 20 September 2019. ${ }^{172}$ The first was: (a) are purely financial losses incurred by an investor on his investment account held at a Dutch bank, as a result of disseminating misleading information by a listed company, sufficient to establish jurisdiction in the Netherlands as forum loci damni in the sense of article 7(2) Brussels Ibis regulation? If any other circumstances are required, what are they?

The second and third questions directly relate to the fact that in these proceedings VEB acted as an association bringing a collective claim on the basis of the Dutch collective action procedure enacted in article 3:305 Dutch Civil Code: (b) does it make any difference in answering question (a) that the association is, by article 3:305a(3) DCC, barred from making a monetary compensation claim in collective action proceedings? (c) Does it make any difference in answering question (a) that in these collective action proceedings the domicile and investment account of the individual investors are not established nor the specific circumstance of the individual purchase transactions? In relation to the territorial effect of the Brussels I regulation, the A-G advised referring two questions to the ECJ: (d) does it matter for jurisdiction if the investment account is held at a bank situated in another court district of the same member state? (e) Can the court addressed in these circumstances on the basis of article 7(2) Brussels Ibis regulation be competent to hear all damage claims from all investors domiciled in any part of the Netherlands or, as in this case, only claims relating to damage actually incurred in the Amsterdam court district? This last question is actually a question as to whether the Shevill

172 HR 20 September 2019, ECLI:NL:HR:2019:1400 (VEB/BP). Conclusion A-G Vlas 8 February 2019, ECLI:NL:PHR:2019:115 (VEB/BP). On 14 June 2019, the Dutch Supreme Court (ECLI:NL:HR: 2019:925) ruled that it will pose questions to the ECJ regarding this matter. The procedural parties are able to submit their points of view before the Supreme Court formulates the definitive questions. 
doctrine also applies to the district level within a member state where direct damages were suffered by the claimant(s).

\section{LEX FORI PROCESSUS: ADMISSIBILITY OF CLAIMS UNDER NATIONAL COLLECTIVE PROCEDURAL LAW}

Except for the exclusive jurisdiction provision (section 6 of chapter II) or prorogation of jurisdiction (section 7) there are three situations in which the court of a member state may assume jurisdiction to hear collective action claims. As forum rei it has jurisdiction to hear claims against a defendant domiciled in that member state irrespective of the domicile of that claimant(s). Therefore, first, the forum rei has jurisdiction in collective action proceedings in regard of damages incurred by various claimants from different jurisdictions. Second, if the unlawful act of the defendant is situated in a court district, the court has jurisdiction to hear tort claims of claimants irrespective of their domicile or where they incurred their damages. Therefore, collective proceedings may be brought against a defendant in the district where they acted unlawfully. Third, the question whether a forum loci damni can establish jurisdiction to hear tort claims depends on the interpretation of the ECJ's case law as discussed in the previous paragraph. Hopefully in the $V E B / B P$ case, the ECJ will give guidance as to whether sustaining direct financial losses on a bank account and being domiciled in (a certain court district of) a member state is sufficient to assume jurisdiction based on article 7(2) Brussels Ibis regulation. If the ECJ answers this question in the affirmative, it may be tempted to rule whether courts in these circumstances may also assume jurisdiction in cases where the individual claimants themselves do not bring the claim, but an association brings a collective action claim in their interest. Depending on the ECJ's interpretation, collective action claims may be brought in the interest of claims in respect of damages occurring in a particular member state before the court(s) of that member state.

Where the court of a member state assumes jurisdiction to hear a collective action claim against the defendant, the court will have to rule on the admissibility of bringing this particular collective claim to that court. First of all, the court has to assess based on its own national substantive of procedural law (lex fori processus) whether the claimant can be admitted in its claim. In some member states, the collective action laws regulated the claim substantively as well as procedurally.

In case law, questions arose as to whether the forum rei should decline jurisdiction because the alleged unlawful act itself as well as the direct consequences of it had to be situated outside the member state. The court had to rule on the sufficiency of the connection to a particular jurisdiction. Under the Brussels Ibis regulation, the forum non conveniens doctrine is rejected; ${ }^{173}$ however, under national procedural rules courts have to deal with these arguments.

In the Shell Nigeria case, The Hague Court of Appeal ruled on the defendant's argument that Dutch collective action proceedings are not to be used for purely foreign events. In this case the oil spill victims in Nigeria for which the association Miliedefensie filed a claim were not deemed to be too loosely connected to the jurisdiction of the Netherlands so as to rule the collective claim inadmissible. In this case, the claim was filed against Shell plc, domiciled in

173 ECJ 1 March 2005 Case C-281/02, ECLI:EU:C:2005:120 (Owusu/Jackson) paras 44-46. 
the Netherlands because of its central administration in The Hague, ${ }^{174}$ in order to determine whether and to what extent Shell owed a duty of care towards the victims in Nigeria. The fact that Nigerian law applies to this particular question is of no relevance to the question of jurisdiction, according to the Court of Appeal. ${ }^{175}$

Furthermore, the Court of Appeal rejected Shell's argument that the question which parties are allowed to proceed with a class action to protect the interests of others as a question of substantive law should be assessed pursuant to the lex causae. In the case at hand Nigerian law would be applicable. Nigerian law does not provide a basis for such collective action proceedings. ${ }^{176}$ According to the court, the possibility for parties to institute a class action under Dutch law has both substantive and procedural law aspects. As a matter of substantive law, the court has to consider whether a material entitlement arises in the case of violation of the (environmental) interests defended by the Dutch environmental association Milieudefensie in other words, whether the facts of the oil spill in Nigeria allow for an action based on tort. These questions, as with the question of validity/allowability, are answered by the substantive law applicable (lex causae) to the tort action. The court ruled that the question whether such a substantive right to action can be enforced in a class action as well as by or on behalf of the person entitled - and if so, to what extent and how - must be characterised under private international law as a procedural matter. These questions are determined by the lex fori processus - in this case Dutch law. ${ }^{177}$

In the Shell Nigeria case, the Court of Appeal did not declare the class action initiated by Milieudefensie on the basis of article 3:305(a) DCC inadmissible because the alleged tortious behaviour was situated outside the Netherlands and the persons whose interests were being served in these proceedings were domiciled outside the Netherlands. These latter international aspects were not considered of influence to rule on the admissibility of the claim under Dutch procedural law.

In the future, this might be different. The bill introducing a collective damage claim action procedure allowing damages to be claimed was adopted by the Dutch Parliament's Lower House on 29 January 2019; it is currently pending for adoption by the Senate. One of the new features is the introduction of stricter rules of admissibility. One of these measures is the introduction of a requirement limiting the scope of class actions available for international cases such as Shell Nigeria. The so-called scope rule is enacted in article 3:305a(3)(b) DCC (new). Accordingly, associations or foundations are only admissible to raise a class action lawsuit if their claims are sufficiently linked to the Dutch jurisdiction. A claim is deemed sufficiently linked to the Dutch jurisdiction if one of the following elements is met: (a) the association or

174 See art 63(1) BrIbis reg.

175 The Hague Court of Appeal 18 December 2015, ECLI:NL:GHDHA:2015:3588 (Oguru, Efanga \& Milieudefensie/Shell) para 3.4 second subparagraph; The Hague Court of Appeal 18 December 2015, ECLI:NL:GHDHA:2015:3587 (Milieudefensie/Shell en Shell/Akpan), para 3.4 second subparagraph; The Hague Court of Appeal 18 December 2015, ECLI:NL:GHDHA:2015:3586 (Dooh/Shell), para 4.4 second subparagraph.

176 The Hague Court of Appeal 18 December 2015, ECLI:NL:GHDHA:2015:3588 (Oguru, Efanga \& Milieudefensie/Shell) para 3.2; The Hague Court of Appeal 18 December 2015, ECLI:NL:GHDHA: 2015:3587 (Milieudefensie/Shell en Shell/Akpan) para 3.2; The Hague Court of Appeal 18 December 2015, ECLI:NL:GHDHA:2015:3586 (Dooh/Shell) para 4.2.

177 The Hague Court of Appeal 18 December 2015, ECLI:NL:GHDHA:2015:3588 (Oguru, Efanga \& Milieudefensie/Shell) para 3.2. 
foundation can plausibly demonstrate that the majority of persons whose interests it seeks to protect with its claim are habitually domiciled in the Netherlands; (b) the defendant is domiciled in the Netherlands and the other circumstances specific to the case also indicate sufficient links to the Dutch jurisdiction; (c) the event(s) on which the claim is based occurred in the Netherlands.

Note that this procedural law aspect does not regard the question of international jurisdiction irrespective whether it is based on the Brussels Ibis regulation or national procedural law. Claims against a defendant domiciled in a member state may be brought before the forum rei. However, it is the applicable national laws that determine whether and on what conditions a particular action may be brought by a particular claimant and on whose behalf. Courts in member states may thus rule positively on their jurisdiction to hear a class action and declare the claim itself inadmissible because of an insufficient link to that jurisdiction. ${ }^{178}$

\section{COORDINATION AND CANALISATION OF COLLECTIVE PROCEEDINGS: LIS PENDENS AND RELATED ACTIONS}

\subsection{Introduction}

International cases involving mass damage attract many procedures in different jurisdictions. An example is the Volkswagen case. As a result of the Diesel software scandal different lawsuits are pending before courts in different states against the German car manufacturer Volkswagen AG. The scandal broke out in the US, with Volkswagen attracting a fine from US authorities including the Environmental Protection Agency. As a result, class actions were instituted before US courts on behalf of car owners as well as VW shareholders in the US.

Because of the 2010 US Supreme Court ruling in Morrison v. National Australia Bank, the securities class actions in the US against non-US domiciled defendants are limited to claims on behalf of investors buying shares in the US either directly or via a US stock exchange. ${ }^{179}$ Therefore, after 2010, actions before courts in member states against defendants domiciled in the EU surged. In the Volkswagen case, shareholder class action proceedings are pending before the Braunschweig District Court as forum rei, ${ }^{180}$ and the Amsterdam District Court as forum loci damni.

A more recent example is the Steinhoff case. The furniture manufacturer moved its business and company from Germany to South Africa in the 1960s. In 2015, corporate restructuring established the holding company Steinhoff International NV in Amsterdam. In Europe, various collective action proceedings are pending before the Amsterdam District Court as well as the Frankfurt District Court.

Such international class action cases, arising from the same event and against the same defendant, and sometimes on behalf of the same claimants, give rise to private international law issues of lis pendens and related actions.

178 Cf. the advice on the scope rule by the Dutch State Committee on Private International Law and the Advisory Committee on Civil Procedure Law, 1 April 2016. Kamerstukken II, 2016/17, 34 608, nr. 3 (Explanatory Note), Annex.

179 US Supreme Court, Morrison v. National Australia Bank 130 S.Ct. 2869.

180 LG Braunschweig 31 May 2016, 5 O 158/16 (VW) Musterverfahrensantrag. 
Depending on the national applicable law, various class action proceedings may be initiated by several claimants regarding the same facts against the same defendant(s) before the same or different courts. At the national as well as at the international level there is a need to coordinate and canalise (collective) claims regarding the same dispute, the same facts and/or the same causes. Coordination and canalisation of these claims and proceedings may be brought about by procedural or substantive measures.

There is no treaty between the EU and the US providing rules to coordinate and canalise such proceedings. In intra-EU cases, the Brussels Ibis regulation may provide some guidance. Cases pending before different national courts in different member states within the EU are regulated by the Brussels Ibis regulation. For reasons of efficiency and fairness, rules on lis pendens and related actions may prevent an undue burden on the defendant as well as the claimants. The latter are benefited by more expedient rulings on their possible compensation of losses when adequate rules of coordination and canalisation are applied. Different procedures before different courts may not only result in conflicting outcomes but also serve as an impediment to recognition and enforcement of possible judgment in the various jurisdictions, as well as possibly reducing access to justice because of extra litigation costs involving the various proceedings. It must be noted that no specific rules on lis pendens or related actions in class action proceedings are enacted in the Brussels Ibis regulation. This regulation does not provide any rules specific to class action proceedings.

\subsection{Lis Pendens}

Coordination of cases with a cross-border element is enacted in the lis pendens rule of the Brussels Ibis regulation. On the basis of article 29 Brussels Ibis regulation, lis pendens rules apply when proceedings involving the same cause of action and between the same parties are brought before courts in different member states. In a case of lis pendens, any court other than the court first seised shall ex officio stay its proceedings until the court first seised has ruled on its jurisdiction. ${ }^{181}$ In the case that the court first seised establishes jurisdiction, any other court than the court first seised has to decline jurisdiction in favour of that court. ${ }^{182}$

In view of the objective of lis pendens, that is, preventing irreconcilable, inconsistent judgments by courts in different member states in essentially the same matter that are automatically recognised, ${ }^{183}$ the conditions for its application are strict. The courts seised after the first one are required ex officio to stay proceedings until the first court rules on jurisdiction. Because of this strictness, the conditions are strict as well. There must be a tripling of identities between the different cases: ${ }^{184}$ first of all, an identity of litigating parties; second, an identity of cause - the same facts and rules of law must be relied upon as the basis for the actions before the different courts; third, an identity of object - the same objective or outcome must be sought in the different proceedings. The court has to rule in regard of the aforementioned cause and object by reference to the claims in the respective actions; the defences to those claims are irrelevant.

181 Art. 29(1) BrIbis reg.

182 Art. 29(3) Bribis reg.

183 Art. 36 Brlbis reg.

184 Glencore International AG v. Shell International Trading and Shipping Co Ltd [1999] 2 Lloyd's Rep 692 at 697. 
In the Tatry case, ${ }^{185}$ the ECH held that the lis pendens rule applies in the case that two proceedings are brought before different courts whereby in one, claimants demand compensation, and in the other a request is made to declare that the party against whom the former action is brought is not liable to pay compensation to the aforementioned claimant. In Tatry the parties were identical and hence lis pendens was applicable.

However, the ECJ also ruled that parties may be deemed the same where their interests are considered identical and indissociable from each other. One of the indications of such an identical and indissociable interest is the fact that a judgment delivered against one of them would have the force of res judicata as against the other. In the Drouot case the relevant claims were brought by the insurer and the insured. In that case, it did not appear to the ECH that 'the interests of the insurer of the hull of the vessel can be considered to be identical to and indissociable from those of its insured, the owner and the charterer of that vessel'. ${ }^{186}$

In class action proceedings the question of lis pendens under the article 29 Brussels Ibis regulation regime is focused on the individual class members and the claimant organisations acting in their interest. For example: a Dutch association or foundation brings a claim on the basis of article 3:305a DCC against a defendant domiciled in the Netherlands requesting the forum rei a declaratory judgment that the defendant acted tortiously towards the group whose interests it serves. Suppose an individual member of that group earlier brought a claim demanding compensation for his losses allegedly caused by the same defendant before a court in Germany as forum loci damni.

In principle, the question of lis pendens only arises if the persons bringing the compensation claim is a member of the group whose interests are served by the organisation filing the collective action claim. Claims by individuals not part of the group can be disregarded in relation to lis pendens issues. In the case that the collective proceedings are not purely collective proceedings, in the sense that in fact individual claims are bundled by transfer of claim or power of attorney or any other form of procuration or mandate, there is no real dispute. The parties are identical and the latter seised courts have to stay proceedings.

However, if the collective proceedings are truly collective, meaning that no individual claims were transferred to the claimant in the collective proceedings or to the claimant individually mandated to act on the individual claimant's behalf, the question of lis pendens is more complex. The claimant in the collective proceedings will act in the interest of a group of alleged victims with an identical alleged tortfeasor. The individual members of the group are unknown; the mere description of their characteristics and the events giving rise to the collective claim suffices. In this way, the court can rule at an abstract level on the collective claim. Lis pendens questions only arise in the case that one of the parties belongs to the group in whose interest the collective proceedings are brought.

In the aforementioned Steinhoff case the Amsterdam District Court ruled that the demand of the defendant company Steinhoff, domiciled in the Netherlands, to stay proceedings due to lis pendens was dismissed. The individual investor seising the Frankfurt District Court before the association brought its collective claim before the Amsterdam District Court was not individually represented in the latter. Therefore, the court rejected staying the collective proceedings. ${ }^{187}$

\footnotetext{
185 ECJ 6 December 1994 Case C-406/92, ECLI:EU:C:1994:400 (Tatry), para 34.

186 ECJ 19 May 1998 Case C-351/96, ECLI:EU:C:1998:242 (Drouot), para 23.

187 Amsterdam District Court 26 September 2018 ECLI:NL:RBAMS:2018:6840 (VEB/Steinhoff), para 4.5.
} 
The court did not elaborately assess whether the individual claimant belonged to the group in whose interest the collective action proceedings are conducted. The court lacked any specific rules or ECJ interpretation on dealing with collective actions where interests are represented without an individual mandate.

Another complicating factor was the German investor's filing of a request to open the $\mathrm{KapMuG}$ proceedings. As mentioned in paragraph 3.3.1, the KapMuG procedure is first of all an instrument to canalise claims similar in its facts, causes and identical in its defendant(s). ${ }^{188}$ It is similar to the possibility for Dutch courts to refer a question for preliminary ruling to the Dutch Supreme Court. District courts (Landgericht, LG) in Germany may, upon request by one of the parties or ex officio, submit common questions of fact and law arising in at least ten different pending proceedings against an identical defendant(s) to a OLG. The LG will appoint a model claimant and defendant, who will proceed at the OLG. On the basis of the OLG's model case judgment (Musterentscheid), the district courts will rule on the pending damage claims of the individual investors. ${ }^{189}$ In the model case judgment, the OLG rules on the submitted common questions of fact and law. Even though a defendant's behaviour is deemed tortious towards the claimant group, the damage claim of an individual investor may be dismissed because of the individual characteristics of the claimant, for example, when claiming shareholder is also director of the company from which he seeks compensation because of the director's misbehaviour. In the case from which this example is drawn, the company did not commit a tort in regard of that particular claimant. ${ }^{190}$

In the Steinhoff case the Amsterdam District Court could dismiss the lis pendens claim on the basis that the request to open the KapMuG procedure was filed after the class action claim was submitted to the Amsterdam District Court. Furthermore, there were not at least nine other claims pending before the Frankfurt District Court. Even if the KapMuG proceedings were pending before the OLG Frankfurt, the Amsterdam District Court deemed the fact that the parties were not individually represented by VEB in their collective proceedings relevant to dismiss lis pendens. ${ }^{191}$ As mentioned earlier, as yet there is no clear guidance in this regard from the Brussels Ibis regulation or the ECJ.

The conditions for lis pendens under article 29 Brussels Ibis regulation are strict. Parties, causes and objects in the actions before the courts of different member states must be identical. This strictness is related to the objective of article 29 , that is, preventing irreconcilable, inconsistent judgments by different courts that must be automatically recognised under the Brussels Ibis regime. Furthermore, the consequences of lis pendens are serious; courts seised after the first one do not have discretion to stay proceedings, they have to. Because of the strict conditions to apply article 29 Brussels Ibis regulation, lis pendens cannot be relied effectively to coordinate cross-border mass damage claims in the EU. In most cases the parties involved in the various (collective) proceedings before the courts in different member states are not identical.

188 Explanatory Notes to the Reform Act introducing the KapMuG (Begründung zu Gesetz zur Reform des KapitalanlegerMusterverfahrensgesetzes) BT-Drs. 851/11, p.32.

189 Another possiblity is that the model claimant and model defendant reach a settlement after the OLG's model case judgment. In that case the model claimant and the model defendant may end proceedings by approval of this settlement by the OLG and the individual claimants not opting out. $§ 23$ jo. $\S 17$ KapMuG.

190 Cf. Dutch Supreme Court 23 February 2007, ECLI:NL:HR:2007:AZ6219 (Io Vivat).

191 Para 4.6. 


\subsection{Related Actions}

On the basis of article 30 Brussels Ibis regulation, any court other than the court first seised may stay its proceedings if the pending cases are related actions. Unlike with lis pendens, its application is not conditional on the parties being identical. Furthermore, it is a discretionary power for the courts; unlike lis pendens motions, courts may refuse to grant them even though the conditions are met. Actions are deemed to be related where they are so closely connected that it is expedient to hear and determine them together to avoid the risk of irreconcilable judgments resulting from separate proceedings. ${ }^{192}$ Its purpose is to improve the coordination of the exercise of judicial functions within the EU and to avoid conflicting and contradictory decisions. For short, article 30 Brussels Ibis regulation aims at facilitating the proper administration of justice including in collective proceedings. Article 30(2) Brussels Ibis regulation specifically provides courts the power, on the application of one of the parties, to decline jurisdiction if a related action is already pending before another court at first instance, and the court first seised has jurisdiction over the actions in question and its law permits the consolidation thereof. However, in reality, courts seems reluctant to stay proceedings (article 30(1) Brussels Ibis regulation), let alone decline jurisdiction (article 30(2) Brussels Ibis regulation).

Courts addressed by a motion to stay because of related actions will have to investigate the nature and effect of the different proceedings before the various courts. Courts of a member state may in that regard deem it necessary to inquire as to the collective action law applicable to the claim pending before the other member state's court. The court needs to determine whether that action is so closely connected to the one before it that it is expedient to hear and determine these actions jointly so as to avoid irreconcilable judgments in the separate proceedings.

In the aforementioned Steinhoff case, the Amsterdam District Court made a comparison between the nature and effect of Dutch collective action proceedings and German KapMuG proceedings. The latter is an opt-in model. The effect of an OLG's model case judgment in the KapMuG procedure is determined by German law. ${ }^{193}$ It is limited to claimants whose claim is pending before a district court in Germany, hence the limitation of its effect to cases where a German court has jurisdiction. ${ }^{194}$

The effects of a judgment in collective action proceedings are not limited to any claims pending before a Dutch court. The organisation can file a declaratory claim without any damage claim pending. In fact, the collective action judgment affects all parties belonging to the group, unless a specific opt-out has been made. ${ }^{195}$ Furthermore, the Amsterdam District Court as forum rei has jurisdiction regarding all claims by non-Germany domiciled Steinhoff investors. ${ }^{196}$

After this comparative analysis, the Amsterdam District Court declined the motion to dismiss on the basis of related actions. This particular case serves as evidence that because of the differences in nature and characteristics of the various collective action procedures in the

\footnotetext{
192 Art. 30(3) BrIbis reg.

193 Art. 36 BrIbis reg. jo. 54 BrIbis reg.; Amsterdam District Court 26 September 2018 ECLI:NL: RBAMS:2018:6840 (VEB/Steinhoff), para 4.10.

194 Amsterdam District Court 26 September 2018 ECLI:NL:RBAMS:2018:6840 (VEB/Steinhoff), para 4.11-4.12.

195 Art. 3:305a(5) DCC.

196 Amsterdam District Court 26 September 2018 ECLI:NL:RBAMS:2018:6840 (VEB/Steinhoff), para 4.13 .
} 
member states, courts are not inclined to stay proceedings - let alone decline jurisdiction based on the related action provision in article 30 Brussels Ibis regulation.

\section{RECOGNITION OF JUDGMENT}

\subsection{Recognition of Judgments in Collective Action Proceedings}

Recognition on the basis of the Brussels Ibis regulation on jurisdiction and enforcement of judgment is necessary to render EU-wide binding and preclusive effect (res judicata) to judgments given by courts in member states. Res judicata ensures the court's rulings of the dispute between the litigating parties in a final and nonappealable judgment can no longer be legally challenged. The parties are precluded from relitigation. In order to be recognised under the Brussels Ibis regime, the judgment must qualify as such on the basis of criteria laid down in that regulation.

If a judgment rendered by one of the member state's courts qualifies as a judgment in the sense of article 36 Brussels Ibis regulation, this judgment has to be recognised and executed by all other national courts. ${ }^{197}$ The exact scope of the binding effect of these judgments is determined by the law of the court rendering the recognised judgment (lex fori originis). ${ }^{198}$ The binding and preclusive effect (res judicata) of the court's rulings is determined by the various collective action and/or settlement proceedings in the various legal regimes of member states. The collective action and settlement proceedings in France, Germany and the Netherlands were investigated in section 3 of this chapter, where the scope and binding nature of judgments in the respective collective action or settlement proceedings were also mentioned.

The recognition of a French court's ruling in an action de groupe under article 36 Brussels Ibis regulation is not so problematic. The courts will give a ruling - quite similar to the ruling the Dutch courts will give when the new collective action proceedings enter into force - in which it rules on the kind of losses that will be compensated and the compensation calculation mechanism on an individual basis or per category. The litigating parties to these proceedings can execute the rights provided in this judgment to the individual members of the group.

Given the opt-in nature of both German collective action proceedings, KapMuG and Musterfeststellungsklage, the question of recognition will not frequently arise. Only those parties that voluntarily opt in to these proceedings, either by filing an individual claim at the court or by registration, are bound by the court's judgment. In the KapMuG, settlement aside, the procedure will not end with the OLG judgment on the common questions of fact and law, but the district courts will have to rule on each individual claim. Furthermore, German law specifically provides that those parties that registered their wish to be bound by the OLG judgment are of course bound by its judgment. Similarly, in the Musterfeststellungsklage, parties

197 Art. 39 BrIbis reg.

198 Report on the Convention on jurisdiction and the enforcement of judgments in civil and commercial matters (Signed at Brussels, 27 September 1968) [1979] OJ C59/1 (Jenard Report), art. 26 Brussels Convention, p.43, 48: Recognition must have the result of conferring on judgments the authority and effectiveness accorded to them in the State in which they were given. See also ECJ 4 February 1988, Case 145/86, ECLI:EU:C:1988:61 (Hoffmann/Krieg) para 11 and ECJ 29 April 1999, Case C-267/97, ECLI:EU:C:1999:213 (Coursier/Fortis Bank); ECJ 28 April 2009, Case C-420/07, ECLI:EU:C:2009: 271 (Apostolides/Orams) para 66. 
are only bound by the court's judgment in the collective proceedings if they had registered their claim at the court. By registration they express their wish to be bound by the judgment on their claim in the collective proceedings between an association and the defendant. The ZPO specifically provides that parties registering their claims will be bound by the court's judgment.

The question is whether a declaratory judgment in Dutch collective proceedings is to be recognised under the Brussels Ibis regulation. An argument in favour of recognition is the explanation given in the Jenard report that the parties to the Brussels Convention used the neutral expression 'judgment' in article 26 of the convention (identical definition now in article $3 \mathrm{r}$ of the Brussels Ibis regulation) and omitted the words res judicata in order to ensure that judgments given in interlocutory proceedings that do not always have the force of res judicata, are to be recognised. ${ }^{199}$ Furthermore, it can only be concluded from the Schlosser report that interlocutory decisions which are intended not to govern the legal relationships of the parties but to arrange the further conduct of the proceedings are to be excluded from the recognition regime. ${ }^{200}$

In conclusion, the question whether the court's rulings in collective proceedings based on national law have cross-border, EU-wide binding effect depends on the fact of whether these judgments qualify as 'judgment' in the sense of the Brussels Ibis regulation. This regulation is based on a classic model of adversarial proceedings between an individual claimant and a (or several) defendant(s). However, the Jenard report and the Schlosser report on the interpretation of the Brussels Convention (the predecessor to the Brussels I regulation) give such a wide interpretation to the concept of judgment that they include the declaratory judgment in Dutch collective action proceedings. Consequently, the rulings by the French, German and Dutch courts in their respective judgments have binding effect if courts in other member states are confronted with a claim concerning an identical or similar matter between the same parties.

Given the fact that the French and German collective action procedures are based on the opt-in collective action model, the binding effect of the judgment is limited to the registered claimants and the defendant. Persons who did not opt in (either by filing a claim at the court or by registration) are not precluded from litigating. The court's judgments in collective action procedures have no binding effect for them. In the Dutch collective action procedure, the declaratory judgment produces only a binding effect between the two procedural parties: the claimant association or foundation and the defendant. In principle, the individual members of the group in whose interest the association or foundation initiated the collective proceedings are not bound by this declaratory judgment. Even though there is no legally binding effect, courts confronted with claims by the individual members try to avoid deviating from the collective ruling.

199 Jenard Report, p.43.

200 Report on the Convention on the Association of the Kingdom of Denmark, Ireland and the United Kingdom of Great Britain and Northern Ireland to the Convention on jurisdiction and the enforcement of judgments in civil and commercial matters and to the Protocol on its interpretation by the Court of Justice (Signed at Luxembourg, 9 October 1978) [1979] OJ C59/71(Schlosser Report), para 187. 


\subsection{Recognition of Judgments in Collective Settlement Proceedings}

An out of court settlement concluded between the parties in collective action proceedings under French law has binding effect after court approval only for those persons that explicitly consented to this settlement by opt in. Under German law, persons filing a damage claim or registering their claim at the court are bound by the settlement approved by the OLG under $\mathrm{KapMuG}$ or the court in the Musterfeststellungsklage unless they opt out. In principle, neither French nor German law provides for a binding effect of collective settlements approved by the court to all members of the group in whose interest the settlement was concluded.

However, under Dutch law there is a mechanism to ensure, in an efficient manner, that a collective settlement has binding effect on all group members who do not explicitly reject this settlement. In this procedure the Amsterdam Court of Appeal may declare the settlement binding on all interested persons unless they opt out. Under the WCAM (Dutch Collective Settlement of Mass Damage Act), the interested parties are first of all notified about the contents of the settlement and the request to declare it binding so as to enable them to avail themselves of any procedural means available to support or contest the settlement.

The Court of Appeal only declares the settlement binding if it is regarded as reasonable on the basis of certain criteria - among others, the fairness of the compensation awarded to the victims of this mass damage event. By doing so, the court acts as the guardian of the absent group members. The interested parties are also notified of the court's declaratory judgment so that they are able to use their right to opt out within the term determined by the court.

A possible impediment to recognition of this declaratory judgment is the fact that interested parties, that is, the persons in whose interest the parties concluded the settlement, do not have to be personally notified. If the identity of those persons is known to the requesting parties, they will be notified by registered mail. The WCAM allows potential victims whose identity is not known to be addressed by means of advertisements in newspapers and websites. This form of notification may lead courts in other member states not to recognise the declaratory judgment's binding and preclusive effect on the basis of article 45(2) Brussels Ibis regulation. Article 45(2) prescribes that a judgment is not to be recognised where it was given in default of appearance, if the defendant was not served with the document which instituted the proceedings or with an equivalent document in sufficient time and in such a way as to enable him to arrange for his defence, unless the defendant failed to commence proceedings to challenge the judgment when it was possible for him to do so. The absent group members may be deemed defendants for purposes of applying the Brussels Ibis regulation. ${ }^{201}$

In the $A S M L / S E M I S$ case, the ECJ ruled that a mere formal irregularity, which does not adversely affect the rights of defence, is not sufficient to prevent the application of the exception to the ground justifying nonrecognition and non-enforcement. ${ }^{202}$ On the basis of this analysis of the WCAM procedure and its safeguards, it is concluded that under the Brussels I regulation regime, in principle, all group members - including those absent at the trial - are bound by the Amsterdam court's declaration. Unknown interested parties who have not been reached and therefore had no opportunity to be heard or to opt out, despite being notified

201 Amsterdam Court of Appeal 29 May 2009, ECLI:NL:GHAMS:2009:BI5744, para 5.17-5.19; Amsterdam Court of Appeal 12 November 2010, ECLI:NL:GHAMS:2010:BO3908, para 2.7-2.12.

202 ECJ Case C-283/05, ECLI:EU:C:2006:787 (ASML Netherlands BV/Semiconductor Industry Services $\mathrm{GmbH}(\mathrm{SEMIS}))$ paras 46-47. 
in accordance with the WCAM, could, under particular circumstances, invoke a ground for refusal of recognition on the basis of article 45(2) Brussels Ibis regulation.

\section{CONCLUDING REMARKS}

The Brussels Ibis regime does not have specific provisions dealing with collective action or collective settlement proceedings relating to civil or commercial matters. Therefore, the questions of jurisdiction, lis pendens, related actions and recognition have to be answered by applying the rules designed for classic two-party adversarial proceedings.

Courts in member states of the EU have jurisdiction as forum rei to hear collective action claims against (legal) persons domiciled in that member state. Legal persons are domiciled at the place where they have their statutory seat, central administration or principal place of business. So potentially, legal persons may be sued before three different courts. The forum rei can also be addressed by a request by a representative organisation and an alleged tortfeasor to approve a collective settlement and thereby bind the group members to this settlement.

In mass damage cases involving another member state, legal persons may also be sued by claimants or a representative organisation with collective claims before the courts of the place where the harmful event occurred. Claimants have the choice to bring this claim before the court of the place where they directly incurred their initial losses. In cases of pure economic loss or financial damage, especially securities class actions, questions remain as to where this particular loss must be situated. For the foreseeable time, the ECJ continues to be addressed by preliminary reference to rule on these questions.

Lis pendens aims to prevent the irreconcilable, inconsistent judgments by courts in different member states in essentially the same matter that are automatically recognised under the Brussels Ibis regime. Collective action proceedings brought before courts of different member states about the same mass damage are not likely to fulfil the strict conditions (identity of parties, causes and objects) of lis pendens. The looser conditions of related actions allow courts more flexibility to stay proceedings if another court was addressed earlier in regard of the same mass damage. In reality, courts seem reluctant to stay proceedings (article 30(1) Brussels Ibis regulation), let alone decline jurisdiction (article 30(2) Brussels Ibis regulation).

Under the Brussels Ibis regime, judgments in collective action or settlement proceedings rendered by courts of member states must be recognised by courts in other member states. Its binding effect is determined by the lex fori originis. French and German collective action procedures are based on the opt-in collective action model. Therefore, by nature, the binding effect of the judgment is limited to the registered claimants and the defendant. Persons who did not opt in (either by filing a claim at the court or by registration) are not precluded from litigating. In the Dutch collective action procedure, the declaratory judgment has only a binding effect between the two procedural parties: the claimant association or foundation and the defendant. The individual members of the group in whose interest the association or foundation initiated the collective proceedings are not bound by law, but in practice courts try to avoid deviation from the collective ruling. Collective settlements declared binding by the Amsterdam Court of Appeal in WCAM proceedings bind all members of the group in whose interest the settlement was concluded unless they opt out. Because the WCAM does not require individual notification of the settlement and the WCAM proceedings in all circumstances, there may be grounds in the Brussels Ibis regime for courts in other member states to refuse recognition. Parties 
whose rights may be affected by a judgment should be served with the document instituting the proceedings or with an equivalent document in sufficient time and in such a way as to enable them to arrange the defence of their rights. However, the question whether this should be done individually in all circumstances is yet to be answered by the ECJ. 